\title{
Distribution and Variability of Nitrogen and Phosphorus in the Alluvial, High Plains, Rush Springs, and Blaine Aquifers in Western Oklahoma
}

\section{By CAROL JOHNSON BECKER}




\section{U.S. DEPARTMENT OF THE INTERIOR BRUCE BABBITT, Secretary}

\section{U.S. GEOLOGICAL SURVEY}

ROBERT M. HIRSH, Acting Director

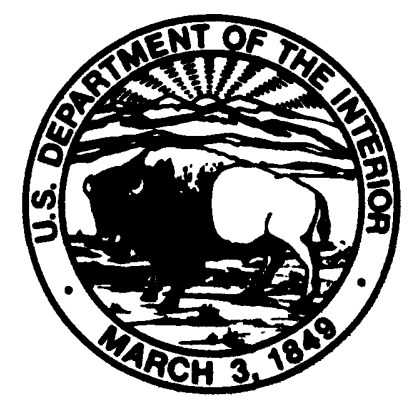

OKLAHOMA CITY, OKLAHOMA 1994

For additional information

write to

District Chief

U.S. Geological Survey

202 NW 66th Street, Bldg. 7

Oklahoma City, Oklahoma 73116
Copies of this report can

be purchased from

U.S. Geological Survey

Earth Science Information Center

Open-File Reports Section

Box 25286, MS 517

Denver, Colorado 80225 


\section{CONTENTS}

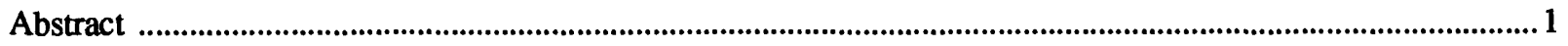

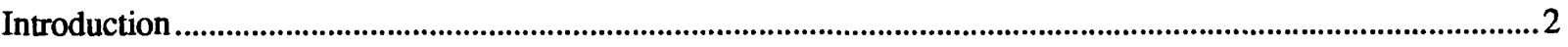

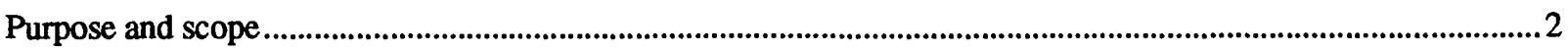

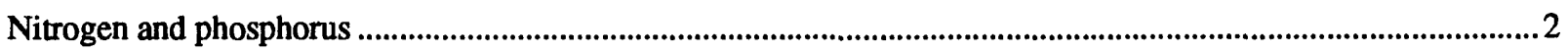

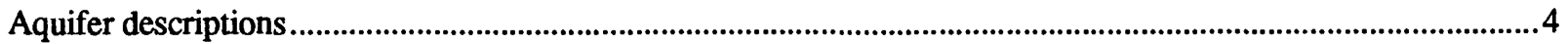

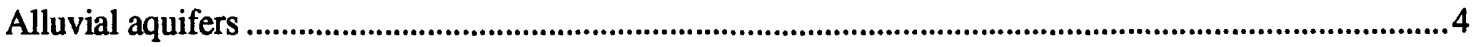

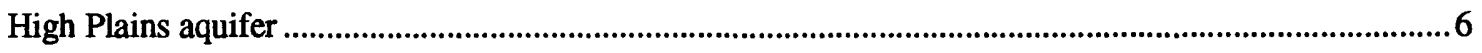

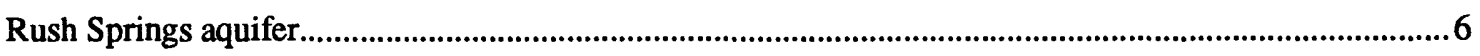

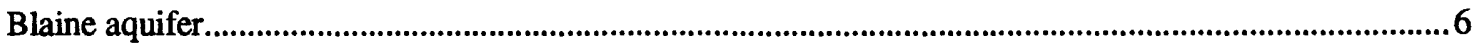

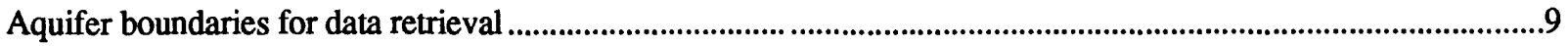

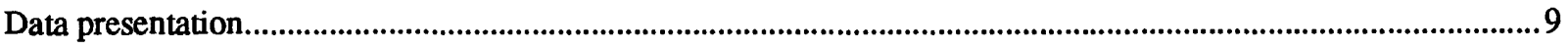

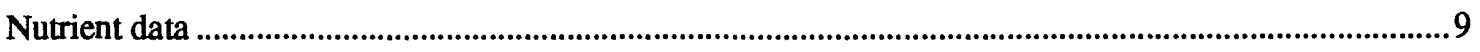

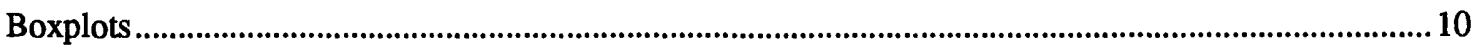

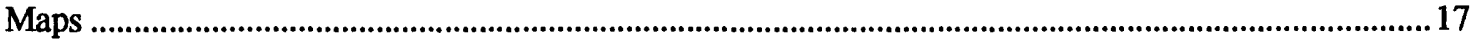

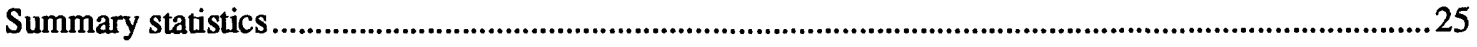

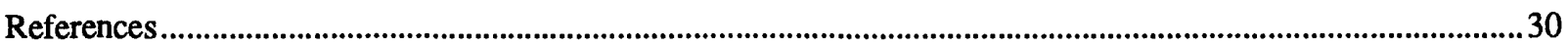

\section{FIGURES}

Figure 1. Index map showing location of aquifers in study area.............................................................

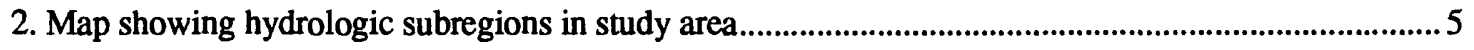

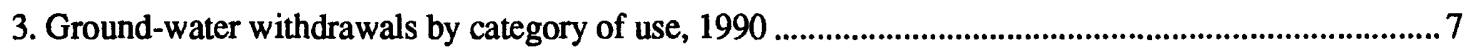

4-5. Boxplots showing variability of nitrogen concentration in ground-water samples from:

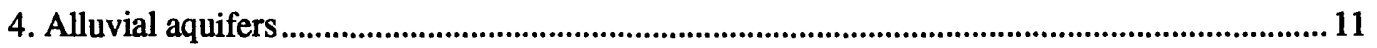

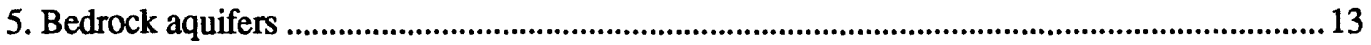

6-7. Boxplots showing variability of phosphorus concentration in ground-water samples from:

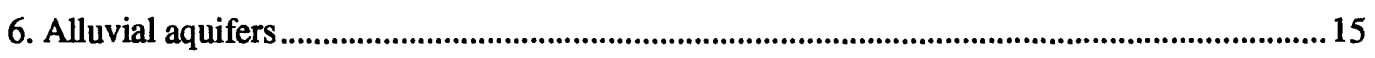

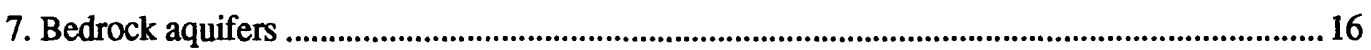

8-11. Maps showing locations of wells where nitrogen was measured in the:

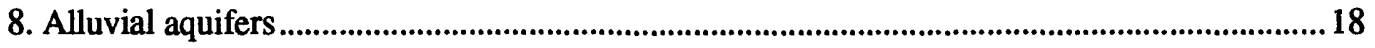

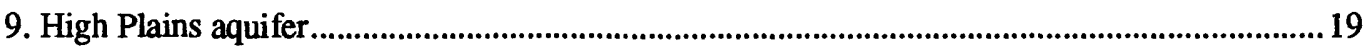

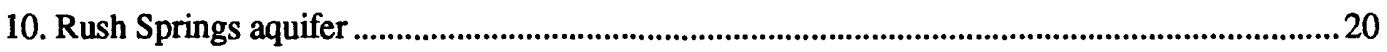

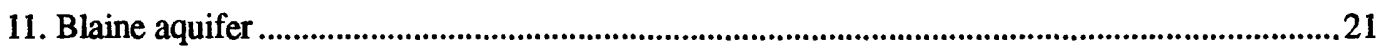

12-14. Maps showing locations of wells where phosphorus was measured in the:

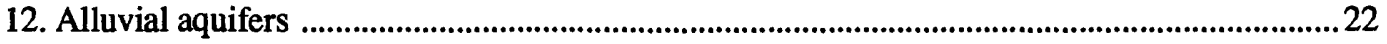

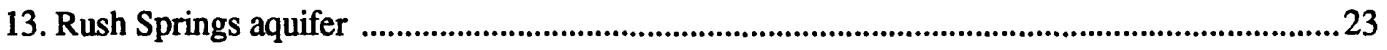

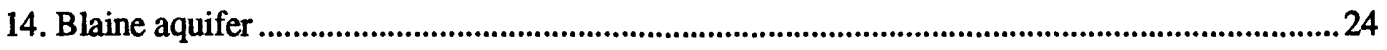


TABLES

Table 1. Maximum contaminant levels for nitrogen in drinking water

.4

2-3. Nitrogen summary statistics for:

2. Alluvial aquifers. .26

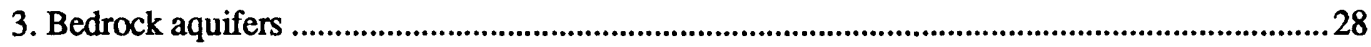

4-5. Phosphorus summary statistics for:

4. Alluvial aquifers .29

5. Bedrock aquifers

CONVERSION FACTORS AND ABBREVIATIONS

\begin{tabular}{rll}
\hline \multicolumn{1}{c}{ Multiply } & By & To obtaln \\
\hline foot (ft) & 0.3048 & meter \\
gallon per minute & 0.06308 & liter per second \\
$(\mathrm{gal} / \mathrm{min})$ & & \\
mile $(\mathrm{mi})$ & 1.609 & kilometer \\
square miles $\left(\mathrm{mi}^{2}\right)$ & 2.590 & square kilometer \\
\hline
\end{tabular}

ADDITIONAL ABBREVIATIONS

$\begin{array}{ll}\mathrm{mg} / \mathrm{L} & \text { milligrams per liter } \\ \mathrm{MCL} & \text { maximum contaminant level } \\ \mathrm{MRL} & \text { minimum reporting level } \\ \mathrm{gal} / \mathrm{min} & \text { gallons per minute } \\ \mathrm{Mgal} / \mathrm{d} & \text { million gallons per day }\end{array}$




\section{DISTRIBUTION AND VARIABILITY OF NITROGEN AND PHOSPHORUS IN THE ALLUVIAL, HIGH PLAINS, RUSH SPRINGS, AND BLAINE AQUIFERS IN WESTERN OKLAHOMA}

\section{By Carol Johnson Becker}

\section{Abstract}

Aquifers are the primary source of water for drinking and agricultural purposes in western Oklahoma. Health concerns about consuming nitrogen and an increased reliance on ground water for drinking necessitate a better understanding of the cause and effect of contamination from nutrients. The purpose of this project was to compile nutrient data from the National Water Information System data base for the alluvial aquifers west of longitude $98^{\circ}$ W. and from three bedrock aquifers, High Plains, Rush Springs and Blaine, and provide this information in a report for future projects and for the facilitation of nutrient source management.

The scope of the work consisted of (1) compiling ground-water quality data concerning nitrogen and phosphorus ions, (2) constructing boxplots illustrating data variability, (3) constructing maps for each aquifer showing locations of wells where nitrogen and phosphorus ions were measured in ground water and where concentrations of nitrate and nitrite, reported as nitrogen, exceed the maximum contaminant level, and (4) calculating summary statistics.

Nutrient data were obtained from the U.S. Geological Survey data base called the National Water Information System. Data were restricted to ground-water samples, but no restrictions were placed on well and water use or date and time of sampling.
Compiled nutrient data consist of dissolved and total concentrations of the common nitrogen and phosphorus ions measured in ground water. For nitrogen these ions include nitrate $\left(\mathrm{NO}_{3}\right)$, nitrite $\left(\mathrm{NO}_{2}\right)$, ammonium $\left(\mathrm{NH}_{4}\right)$, and nitrite plus nitrate $\left(\mathrm{NO}_{2}+\mathrm{NO}_{3}\right)$. All concentrations are reported in milligrams per liter as nitrogen. Phosphorus in ground water is measured as the ortho-phosphate (ortho$\mathrm{PO}_{4}$ ) ion, and is reported in milligrams per liter as phosphorus.

Nutrient variability is illustrated by a standard boxplot. The data are presented by aquifer or hydrologic subregion for alluvial aquifers, with one boxplot constructed for each nutrient compound if more than four analyses are present. Maps for each aquifer show where nitrogen and phosphorus have been measured in ground water and where the concentrations of nitrate and nitrite exceed the maximum contaminant level. A statistical summary for each aquifer and subregion show if censored data were present, number of samples in each data set, largest minimum reporting level for each nutrient compound, percentiles used to construct boxplots, and minimum and maximum values. Also given are the number of wells sampled in each aquifer and the number of wells exceeding the maximum contaminant level. 


\section{INTRODUCTION}

Aquifers are the primary source of water for drinking and agricultural purposes in western Oklahoma. Health concerns about consuming nitrogen and an increased reliance on ground water for drinking necessitate a better understanding of the cause and effect of contamination from nutrients. The purpose of this project was to compile nutrient data from the National Water Information System data base for the alluvial, High Plains, Rush Springs, and Blaine aquifers and to provide this information in a report for future projects and for the facilitation of nutrient source management.

\section{PURPOSE AND SCOPE}

This report provides graphic, tabular, and areal information on the distribution and variability of nitrogen and phosphorus ion concentrations in ground water from alluvial aquifers in the surficial terrace and alluvium located along rivers and their tributaries west of longitude $98^{\circ} \mathrm{W}$. in Oklahoma and from three bedrock aquifers, High Plains, Rush Springs, and Blaine (fig.1).

The scope of the work consisted of: (1) compiling ground-water-quality data concerning nitrogen and phosphorus ions, (2) constructing boxplots illustrating data variability, (3) constructing maps for each aquifer showing locations of wells where nitrogen and phosphorus ions were measured in ground water and where concentrations of nitrate $\left(\mathrm{NO}_{3}\right)$ and nitrite $\left(\mathrm{NO}_{2}\right)$, reported in milligrams per liter $(\mathrm{mg} / \mathrm{L})$ as nitrogen $(\mathrm{N})$, exceed the maximum contaminant levels (MCL's) for drinking water established by the U.S. Environmental Protection Agency (EPA) and State of Oklahoma, and, (4) calculating summary statistics.

All site and nutrient data used for this report were retrieved from the U.S. Geological Survey's data base, National Water Information System. Data compiled were restricted to groundwater samples within specified aquifer boundaries; samples from springs and surface water were not used. As no restriction was placed on date or time of sampling, multiple analyses were available for some sites and in these cases the most recent analysis was used. No restriction was placed on type of well or use of water, which vary for each aquifer depending upon water quality, well yield, and need. A total of 1,133 analyses were used for this report.

\section{NITROGEN AND PHOSPHORUS}

The nutrients nitrogen and phosphorus are essential chemical compounds necessary for life and critical for plant nutrition; however, excessive concentrations of these nutrients in water can have undesirable effects.

Ground water and surface water are vulnerable to contamination when nutrients are leached from sources in the soil and percolate downward into the underlying aquifer or flow overland into rivers, lakes, and ponds. Problems occur when nutrients accumulate in surface waters, causing eutrophication, or in ground water used for drinking, where nitrogen can pose a health risk.

Nitrogen, an essential element for biological processes, is commonly found in waste products from septic tanks, cesspools, animal feed lots, barnyards, and bats (from accumulations of guano) (Hem, 1985). Other sources include municipal and industrial wastewater, nitrogen-based fertilizers, and atmospheric fallout (from combustion of fossil fuel). Nitrogen also occurs naturally in soils from the decomposition of organic material, in some instances at concentrations high enough to cause significant ground-water contamination (Kreitler, 1975).

Nitrogen in ground water exists primarily as the ions ammonium $\left(\mathrm{NH}_{4}\right)$, nitrite $\left(\mathrm{NO}_{2}\right)$, and nitrate $\left(\mathrm{NO}_{3}\right)$. Nitrate, the most chemically stable form of nitrogen in the nitrogen cycle and the most mobile in water, is more likely to be the ion found in waters used for drinking, whereas $\mathrm{NH}_{4}$ and $\mathrm{NO}_{2}$ are most often found in oxygen-depleted waters close to the source of contamination.

Phosphorus is found in naturally occurring sources such as phosphorus-containing rocks, waste products from large concentrations of ducks and cattle, fallout from the atmosphere, and tree leaves (U.S. Environmental Protection Agency, 1986). However, in most populated regions, including Oklahoma, the most important sources of phosphorus are man-made, such as domestic and industrial sewage and fertilizers. 


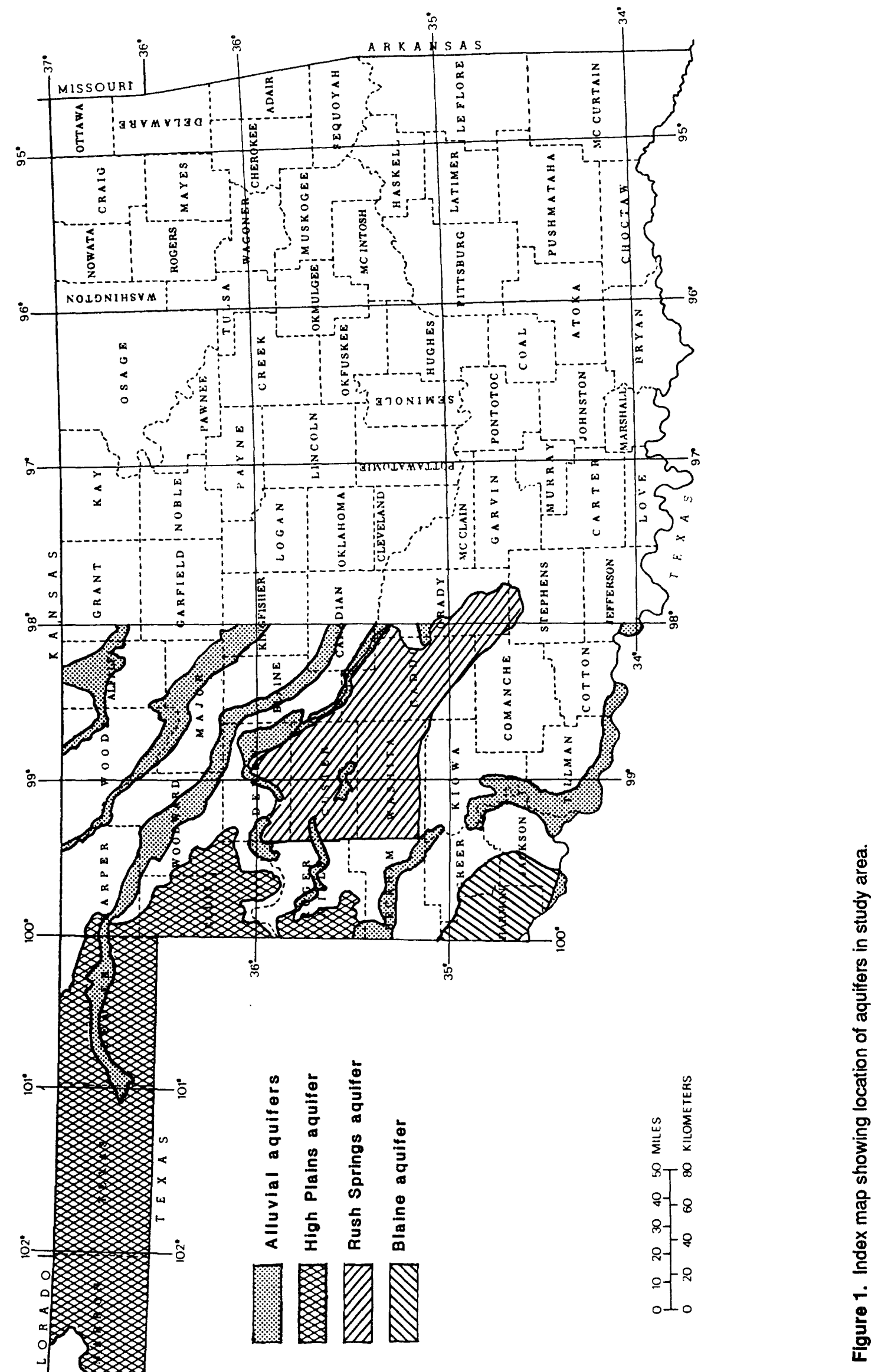


Phosphorus is most commonly a problem in surface waters. In ground water the concentration generally does not exceed more than a few tenths of a milligram per liter because of adsorption by constituents in soils (Hem, 1985).

In water used for drinking, nitrogen as $\mathrm{NO}_{3}$ poses the greatest risk to bottle-fed infants, causing methemoglobinemia (blue baby syndrome) (National Academy of Science, 1977). As a result the EPA (1992) and the State of Oklahoma (Oklahoma State Department of Health, written commun.,1992) have set drinking-water standards regulating the maximum level of nitrogen allowed in drinking water. Table 1 lists the State and Federal MCL's for nitrogen. Unlike nitrogen, phosphorus does not have a MCL. sources for drinking water where water quality allows.

Alluvium is composed of several types of surficial sediments including river alluvium, high and low terrace deposits, and dune sand. River alluvium is the material constantly being eroded, transported, and deposited by a river along its course. The high and low terrace deposits are older river alluvium that has been deposited topographically higher than the present-day river and locally may be overlain by wind-blown accumulations of dune sand. All of these deposits are unconsolidated and, except for dune sand, consist of alternating lenses of clay, silt, sand, and gravel.

Water usage from alluvial aquifers is dependent upon well yield and water quality. Well yields

Table 1. Maximum concentration levels for nitrogen in drinking water. All values reported in $\mathrm{mg} / \mathrm{L}$ as nitrogen (U.S. Environmental Protection Agency, 1992, Oklahoma State Department of Health, written commun.,1992).

\begin{tabular}{lrrrl}
\hline & $\mathrm{NH}_{4}$ & $\mathrm{NO}_{2}$ & $\mathrm{NO}_{3}$ & $\mathrm{NO}_{2}+\mathrm{NO}_{3}$ \\
\hline EPA & Not defined & $1.0 \mathrm{mg} / \mathrm{L}$ & $10.0 \mathrm{mg} / \mathrm{L}$ & $10.0 \mathrm{mg} / \mathrm{L}$ \\
Oklahoma & Not defined & $1.0 \mathrm{mg} / \mathrm{L}$ & $10.0 \mathrm{mg} / \mathrm{L}$ & $10.0 \mathrm{mg} / \mathrm{L}$ \\
\hline
\end{tabular}

\section{AQUIFER DESCRIPTIONS}

Each of the four aquifers studied in this report are an important source of water for various uses. Water quality is variable for each of the aquifers and is an important factor in determining usage type. As a result, nutrient contamination is a greater concern where ground water is utilized for drinking, in contrast to areas where it is utilized for agricultural purposes. The following is a brief description of each aquifer and water use.

\section{Alluvlal Aqulfers}

Alluvial aquifers are found within the alluvium deposited by major rivers and their tributaries in western Oklahoma (fig. 1). They are an important source of water for many uses and because of their high porosities and permeabilities, make ideal normally range from 20 to 600 gallons per minute (gal/min) but may exceed 1,200 gal/min (Pettyjohn, 1991) where conditions permit. The alluvial aquifer may exhibit water-quality characteristics similar to the underlying bedrock aquifer or to the adjacent river, depending upon direction of ground-water flow and degree of hydraulic interconnection among the three. Surface runoff also can have an effect on water quality depending upon agricultural, domestic, or industrial activity in the surface drainage area. As a result, in some areas ground water from alluvial aquifers mixes with highly saline water or nutrient-rich water, and is not suitable for drinking. In water-related studies it is helpful to look at the river with its corresponding drainage basin when ascertaining the effect of contamination on alluvial aquifers. In Oklahoma the U.S. Geological Survey divides river systems and their drainage basins into hydrologic subregions to facilitate the storage and reporting of data. Shown on figure 2 are the 7 hydrologic subregions in the 


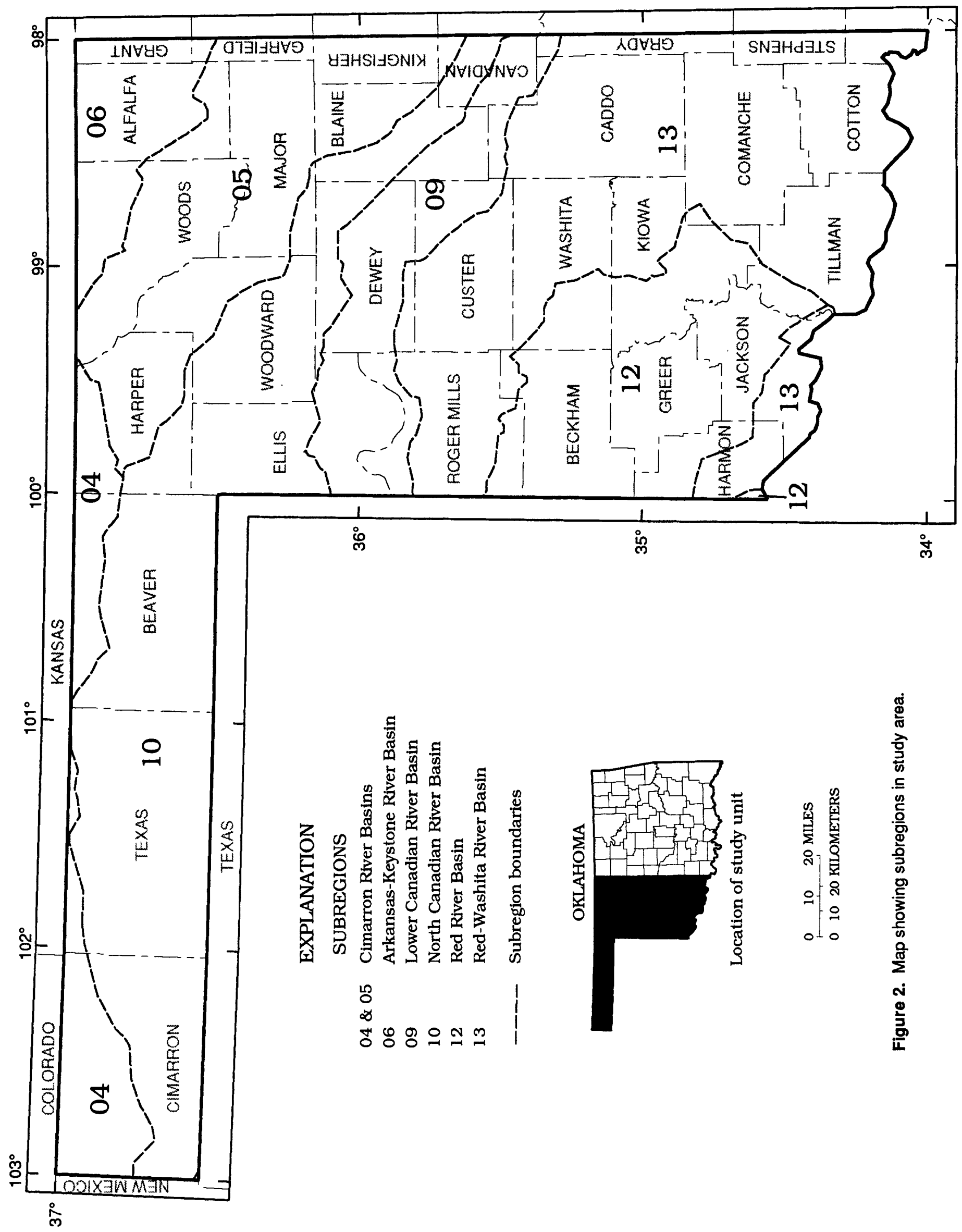


study area and the major river basins they delineate.

\section{High Plalns Aqulfer}

The High Plains aquifer is the principal source of ground water for irrigation in the midwestern United States. In Oklahoma, the High Plains aquifer underlies approximately 7,350 square miles (Havens, 1992) of the Panhandle counties of Cimarron, Texas, and Beaver, and sections of Harper, Ellis, Roger Mills, Woodward, Dewey, and Beckham Counties.

The High Plains region includes parts of Wyoming, South Dakota, Nebraska, Colorado, Kansas, New Mexico, Oklahoma, and Texas. This region was once an alluvial plain that extended eastward from the ancestral Rocky Mountains. Streams flowing eastward dissected the plain and deposited alluvial materials forming the High Plains aquifer (Dugan and Schild, 1992). In Oklahoma the Late Tertiary-aged alluvial deposits that comprise the High Plains aquifer are called the Ogallala Formation and consist predominately of semiconsolidated deposits of interfingering lenses of clay, silt, sand, and gravel. The saturated thickness of these sediments in Oklahoma range from 0 to 656 feet (ft) with more than 50 percent between 0 and $108 \mathrm{ft}$ (Weeks and Gutentag, 1981).

Approximately 363 million gallons per day (Mgal/d) of ground water were pumped from the High Plains aquifer in 1990. About 92 percent was used for irrigation with the remaining water used for stock and public supply (Solley, 1993) (fig. 3).

\section{Rush Springs Aqulfer}

The Rush Springs Sandstone and underlying Marlow Formation constitute the Rush Springs aquifer, an important source of ground water for irrigation and public supply in western Oklahoma.

The Rush Springs Sandstone and Marlow Formation extend throughout western Oklahoma into adjacent sections of Kansas and Texas, but because of variations in permeability and water quality, these formations are considered a major aquifer only in a five-county area in western Oklahoma.
These Oklahoma counties are Custer, Washita, Caddo, and parts of Dewey and Grady.

The Permian-aged Rush Springs Sandstone is described as a poorly cemented, reddish-brown, fine-grained sandstone that locally is silty or argillaceous, and contains several thin but persistent beds of gypsum or anhydrite and dolomite. Total thickness ranges from 0 to $394 \mathrm{ft}$ in the study area (Johnson and others, 1990).

The underlying Marlow Formation consists of reddish-brown, fine-grained silty sandstone, sandy shale, and siltstone with several persistent dolomite and gypsum or anhydrite beds. The total thickness of the Marlow Formation in the study area ranges from 0 to $131 \mathrm{ft}$ (Johnson and others, 1990).

During 1990, approximately 55.0 Mgal/d of ground water were withdrawn from the Rush Springs aquifer. Seventy-eight percent $(42.8 \mathrm{Mgal} /$ d) of the ground water withdrawn was used for irrigation, with the remainder used for public supply, stock, domestic, and commercial purposes (fig. 2).

\section{Blaine Aquifer}

The Blaine aquifer is located in the southwestern corner of Oklahoma and has been used extensively for irrigation since 1942 . The Permian-age Blaine Formation supplies large quantities of highly mineralized water from gypsum and dolomite beds within the formation.

The Blaine aquifer, situated in the Hollis Basin, underlies the southwestern Oklahoma counties of Greer, Harmon, and Jackson and adjacent counties in north-central Texas. The Hollis Basin is a structural basin developed in Early Pennsylvanian time during the uplift and emergence of the Wichita and Red River blocks (Johnson, 1990). It contains approximately 3,300 to $13,100 \mathrm{ft}$ of Late Cambrian through Permian strata. The Blaine aquifer is described as the uppermost 164 to $213 \mathrm{ft}$ of flat-lying Permian rocks in the basin.

The Blaine aquifer is divided into two members, each containing alternating beds of gypsum or anhydrite, dolomite, and shale. The two members are the upper Van Vactor Member and the lower Elm Fork Member (Havens, 1977). The Van Vactor Member is about $98 \mathrm{ft}$ thick and is composed of six evaporite-clastic sequences. The Elm 

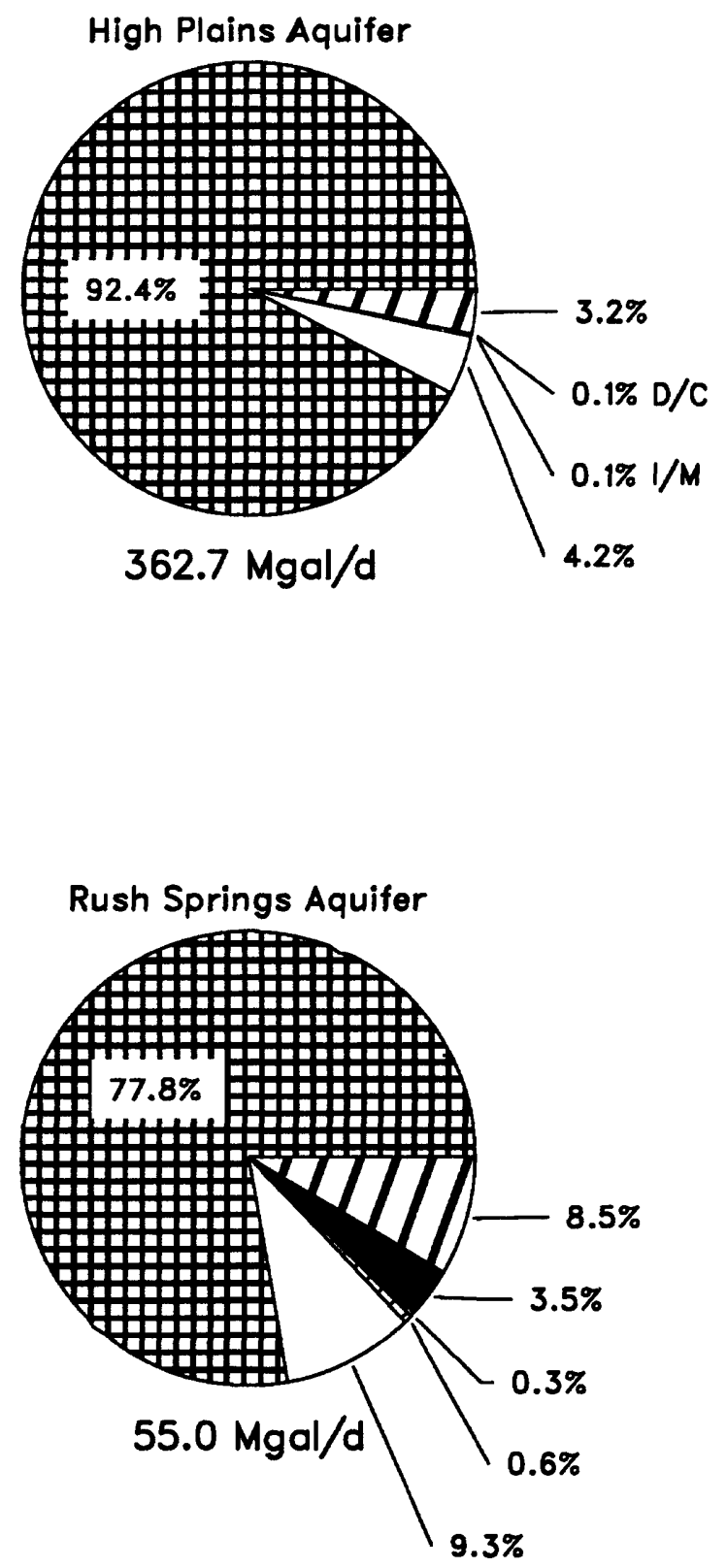

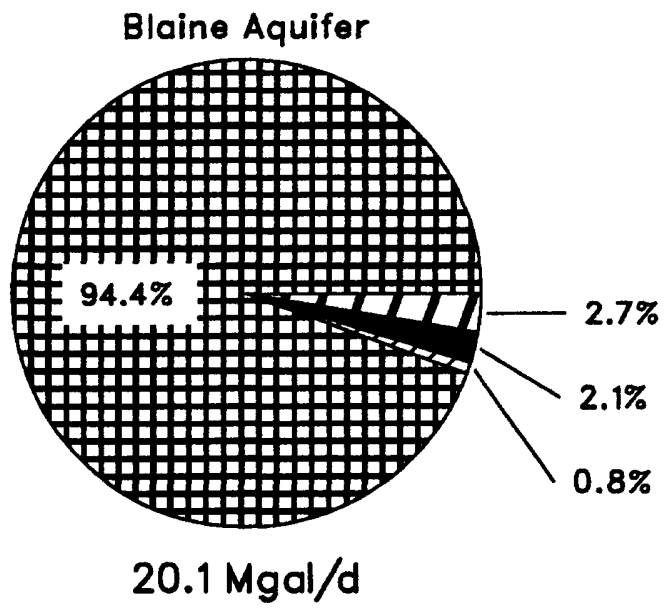

EXPLANATION

Ground water use categories

Irrigation

$\square$ Public supply

$E]$ Industrial/Mining ( $/ / M)$

$\checkmark$ Thermoelectric

Domestic/Commercial (D/C)

$\square$ Stock

92.4\% Percent of total withdrawn from aquifer

\section{A, Bedrock aquifers}

Figure 3. Ground-water withdrawals by category of use, 1990. A, Bedrock aquifers; B, alluvial aquifers by subregion. [mgal/d, million gallons per day. Data from Solley, Chase, and Perlman, 1993] 
Subregions $04 \& 05$

Cimarron River Basin

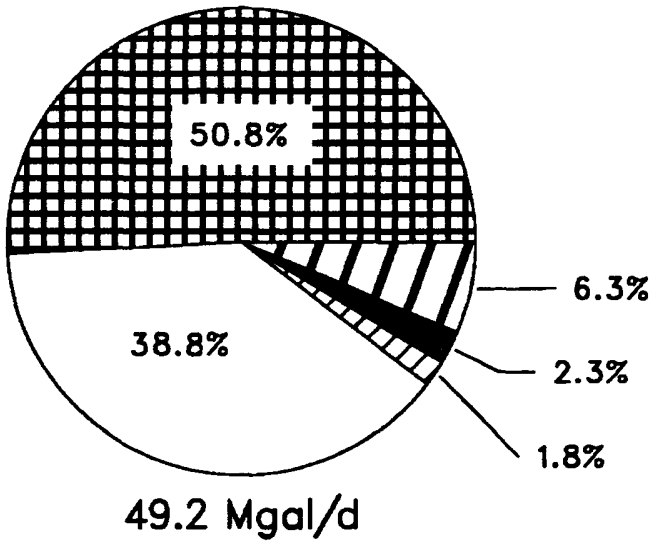

Subregion 09

Lower Canadian River Basin

$8.6 \%$

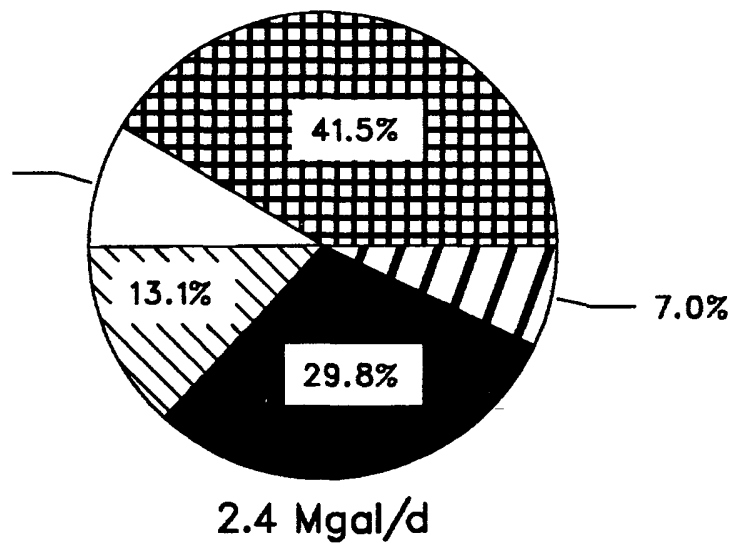

Subregion 12

Red River Basin

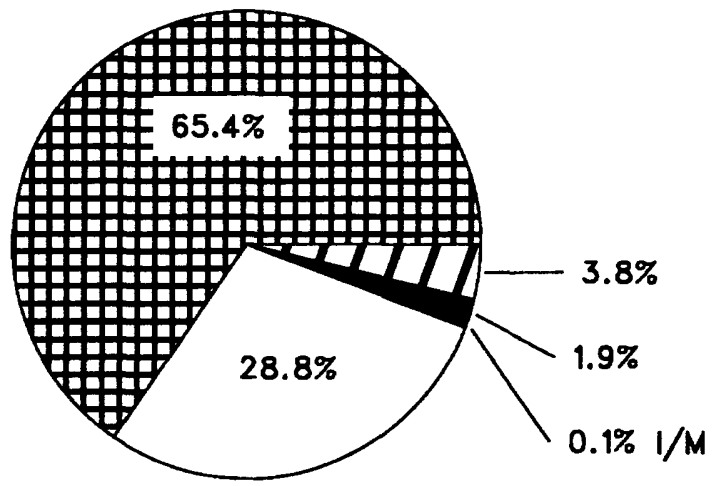

$18.3 \mathrm{Mgal} / \mathrm{d}$
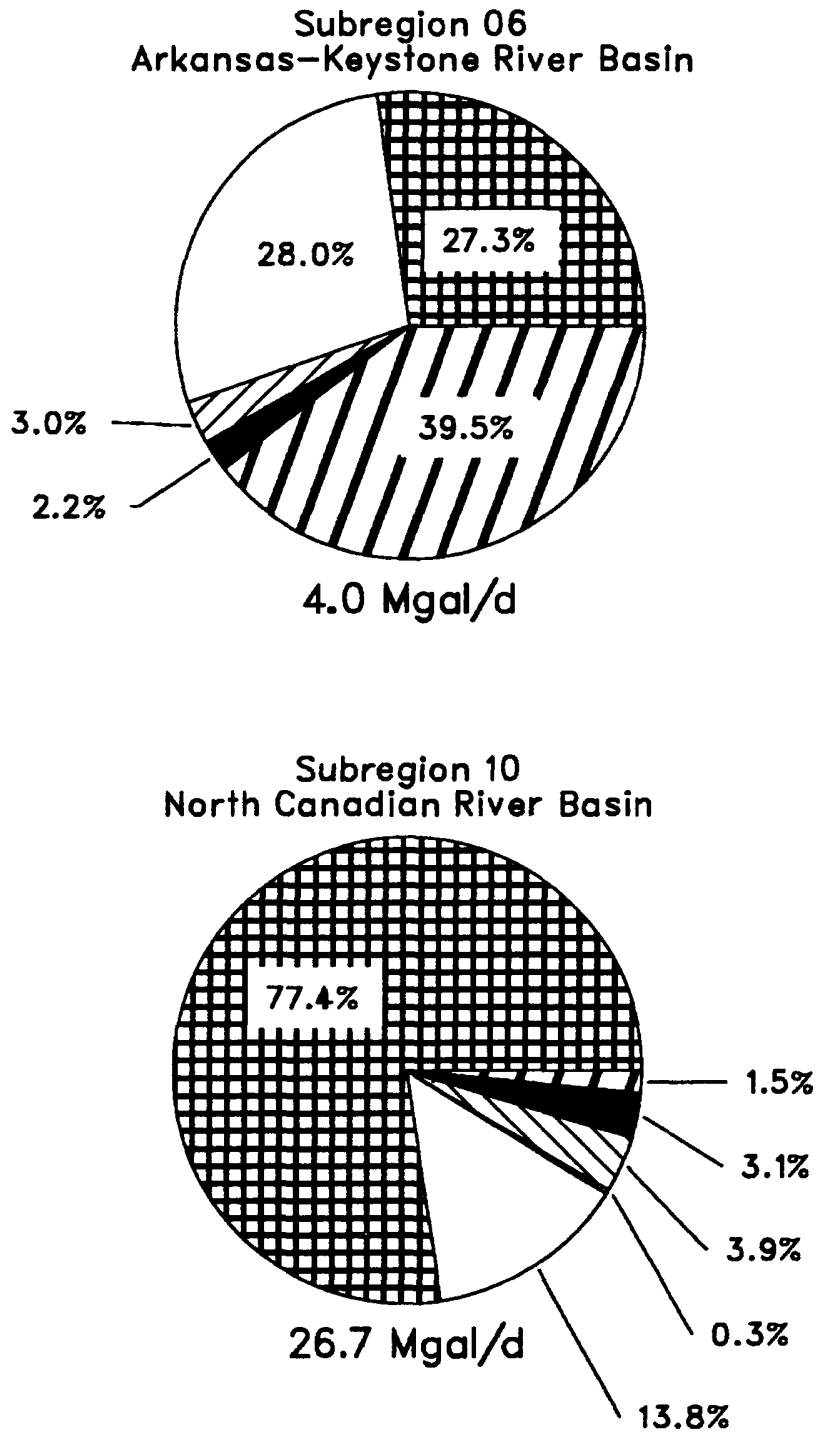

Subregion 13

Red-Washita River Basin

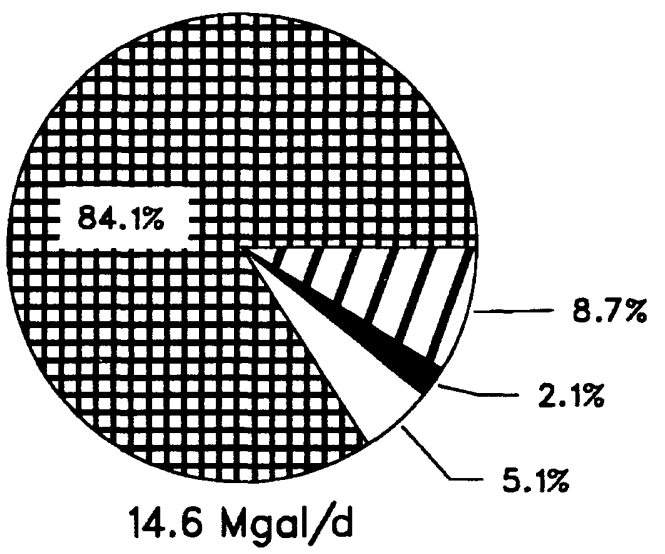

$B$, Alluvial aquifers

Figure 3. Ground-water withdrawals by category of use, 1990. A, Bedrock aquifers; B, alluvial aquifers by subregion-Continued 
Fork Member is about $115 \mathrm{ft}$ thick and consists of three evaporite-clastic sequences. The Blaine aquifer is underlain by the Flowerpot Shale and overlain in the western part by the Dog Creek Shale, which is considered a confining unit where greater than $98 \mathrm{ft}$ thick. (Runkle and Johnson, 1988).

The Blaine aquifer is highly sensitive to contamination from surface sources because of its karstic nature. Where gypsum beds have undergone dissolution, an extensive network of karstic features have been created, such as sinkholes, caves, disappearing streams, and springs (Runkle and Johnson, 1988). These features act as conduits and facilitate the recharge of large quantities of water from storm runoff or irrigation, which may contain nutrients and other chemicals.

In 1990 approximately $20 \mathrm{Mgal} / \mathrm{d}$ of ground water were withdrawn from the Blaine aquifer, with over 94 percent used for irrigation (fig. 3). The high concentration of sulfate and high total dissolved solids (averaging 3,100 mg/L)(Runkle and Johnson, 1988), makes ground water from the Blaine aquifer unsuitable for drinking.

\section{AQUIFER BOUNDARIES FOR DATA RETRIEVAL}

In general, aquifer boundaries are determined by erosional termination of the aquifer formation, insufficient yield for intended use, or the point at which water quality prohibits usage. These three conditions in addition to man-made geographic boundaries determined the aquifer boundaries for data retrieval.

Wells in the alluvial aquifers were restricted to terrace and alluvium deposits along rivers and major tributaries west of longitude $98^{\circ} \mathrm{W}$. in Oklahoma. Generally, alluvial aquifers are considered a part of the underlying bedrock aquifer when hydraulically interconnected. For this study, nutrient data from alluvial aquifers were compiled separately and were presented by hydrologic subregion. A subregion is a subdivision of a hydrologic unit, developed by the U.S. Geological Survey to provide a standardized base to manage data and information for a river system and its drainage basin. A hydrologic subregion as described by Seaber and others (1987) is "the area drained by a river sys- tem, a reach of a river and its tributaries in that reach [or] a closed basin." The study area is divided into six subregions for data retrieval each representing a major river basin: subregions 04 and 05, the Cimarron River Basins; subregion 06, the Arkansas-Keystone River Basin; subregion 09, the Lower Canadian River Basin; subregion 10, the North Canadian River Basin; subregion 12, the Red River Basin; and subregion 13, the Red-Washita River Basin (fig.2).

All wells located in the High Plains and Blaine aquifers are within geographic boundaries determined by the state line or by erosional limits. The basin boundaries for the Rush Springs aquifer are the county lines and the Canadian River. These geographic boundaries are used for convenience, but coincide with a decrease in permeability and water potability, which restricts water use north and west of these boundaries. Only analyses of samples known to be from selected formations within the aquifer and to be associated with a known geographic location were used.

\section{DATA PRESENTATION}

Nutrient data compiled from the four aquifers are listed as dissolved and total concentrations of the common nitrogen and phosphorus ions found in ground water. To illustrate the variance in data, a set of boxplots and a statistical summary were constructed for each aquifer and subregion. Maps of each aquifer show wells where nitrogen and phosphorus were measured and where the MCL's for nitrogen were exceeded.

\section{Nutrlent Data}

Nitrogen in ground water is reported as the amount of nitrogen in $\mathrm{NO}_{3}, \mathrm{NO}_{2}, \mathrm{NH}_{4}$, and in the combination of $\mathrm{NO}_{2}+\mathrm{NO}_{3}$, which in some cases is used as an estimate for $\mathrm{NO}_{3}$. Phosphorus in ground water is reported as the amount of phosphorus in the ion ortho- $\mathrm{PO}_{4}$. When analyzing for these ions, laboratories report concentrations as total and dissolved. A total concentration is representative of unfiltered water, indicating the quantity of dissolved and particulate compounds present in the water sample. A concentration reported as dis- 
solved indicates that the water sample was filtered through a 0.45 -micron pore-size filter before analyzing.

Nitrate is the most common nitrogen ion measured and, when comparing older data to more recent data, the reader must be aware that older analyses reported nitrate as $\mathrm{mg} / \mathrm{L}$ as $\mathrm{NO}_{3}$ instead of $\mathrm{mg} / \mathrm{L}$ as $\mathrm{N}$, which is standard today. The MCL for nitrate reported as $\mathrm{NO}_{3}$ is $40 \mathrm{mg} / \mathrm{L}$, while the $\mathrm{MCL}$ for nitrate reported as $\mathrm{N}$ is $10 \mathrm{mg} / \mathrm{L}$. This discrepancy in reporting can lead the reader to believe that $\mathrm{NO}_{3}$ concentrations have decreased over time when in fact only the reporting units have changed. Other factors that must be considered when comparing nutrient data are changes in sampling, preservation, and analytical techniques over the past 50 years. These changes may give the data an indeterminate variability that must be taken into consideration when interpreting the data.

Advances in technique give greater precision and more accurate determination of nutrient concentration, usually resulting in a smaller minimum reporting level (MRL). Data used in this report were not restricted by date and, as a result, the MRL for a nutrient compound may have changed several times. All data that are reported as less than the MRL, which includes non-detectable concentrations, are referred to as censored data.

\section{Boxplots}

For this report a standard boxplot is used to show data variability and to aid in comparison between data sets.
Boxplots for nitrogen and phosphorus data sets are separate and are presented by aquifer or hydrologic subregion for alluvial aquifers. One boxplot was constructed for each nutrient species if more than four analyses were present. The lower and upper limits of the box are defined as the 25th and 75th percentiles of that data set. The 25th percentile or lower box end is a value that exceeds no more than 25 percent of the data and is exceeded by no more than 75 percent of the data. The 75 th percentile or upper box end is a value that exceeds no more than 75 percent of the data and is exceeded by no more than 25 percent of the data. The center line or 50th percentile represents the median value. The box length represents the variation in data, also called the interquartile range (IQR). The whiskers extend to the largest and smallest data values within 1.5 times the length of the box (called a step, which is 1.5 times the interquartile range). Data values between one and two steps from the box in either direction are represented by an asterisk. Data values farther than two steps from the box are represented by a circle (D. Helsel, written commun., 1989). The lower boundary of each boxplot is determined by the largest (least sensitive) MRL for that nutrient compound. All concentration values below the largest MRL, referred to as censored data, are represented by a value equal to the largest MRL.

Boxplots illustrating nutrient variability are shown on figures $4,5,6$, and 7 . Because there are no phosphorus data available for the High Plains aquifer and fewer than the four required analyses for alluvial aquifers in subregions 06, 09, and 10, boxplots were not constructed for these aquifers. 

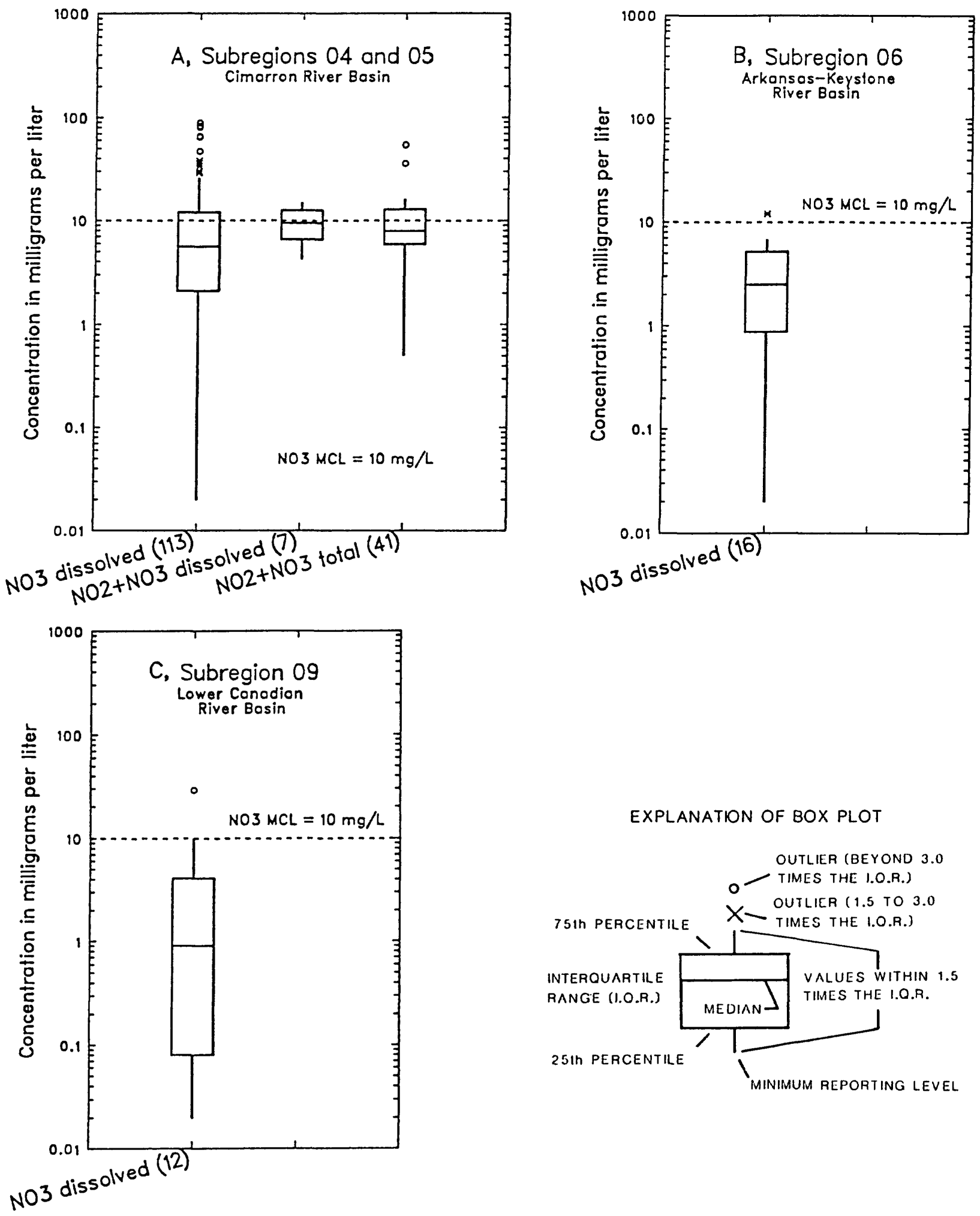

Figure 4.-Boxplots showing variability of nitrogen concentration in ground-water samples from alluvial aquifers: A, Subregions 04 and 05, Cimarron River Basin; B, Subregion 06, Arkansas-Keystone River Basin; C, Subregion 09, Lower Canadian River Basin; D, Subregion 10, North Canadian River Basin; E, Subregion 12, Red River Basin; F, Subregion 13, Red-Washita River Basin. All concentrations reported in $\mathrm{mg} / \mathrm{L}$ as nitrogen. Total number of samples in parentheses; $\mathrm{MCL}$, maximum contaminant level. 

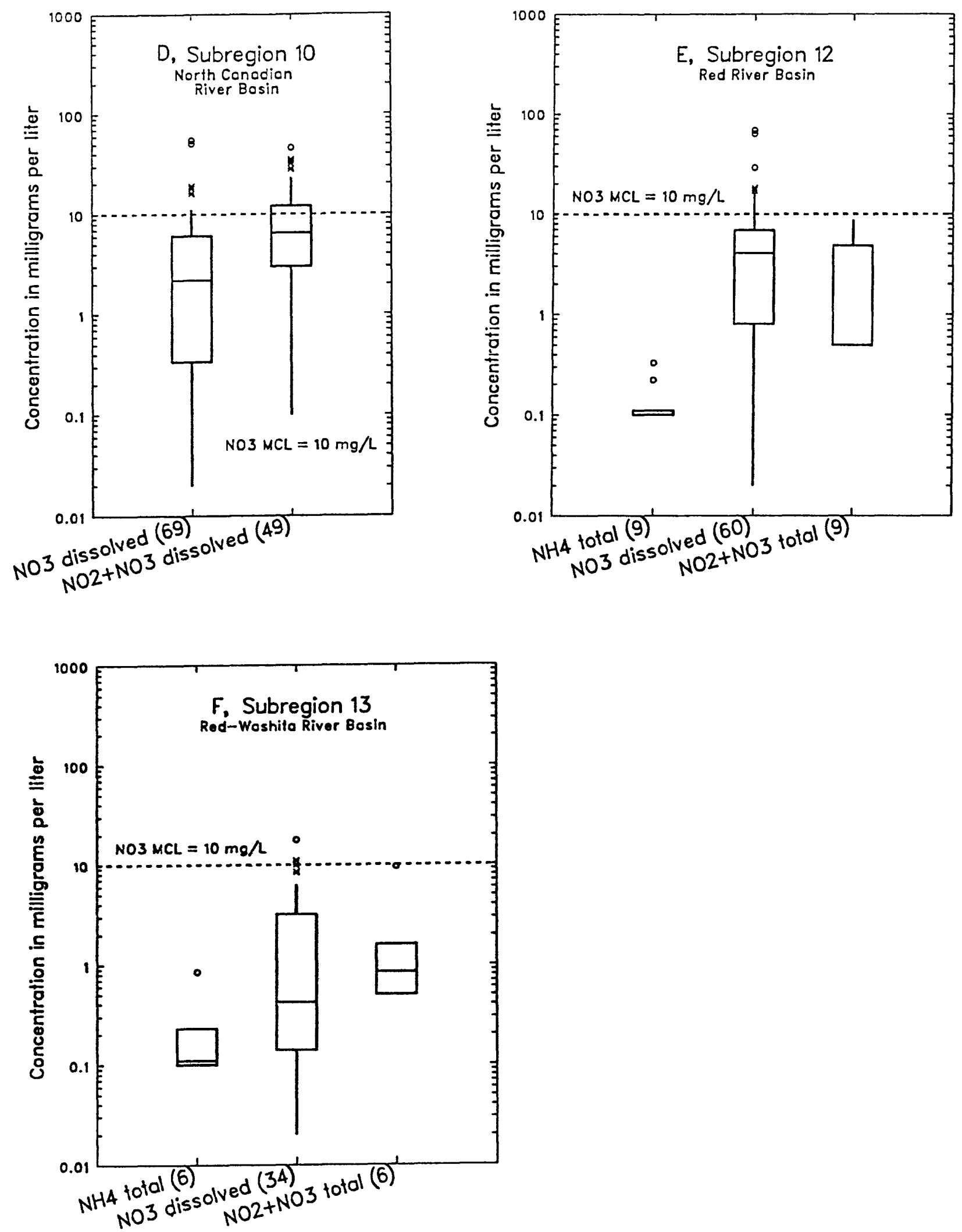

Figure 4.-Boxplots showing variability of nitrogen concentration in ground-water samples from alluvial aquifersContinued. 

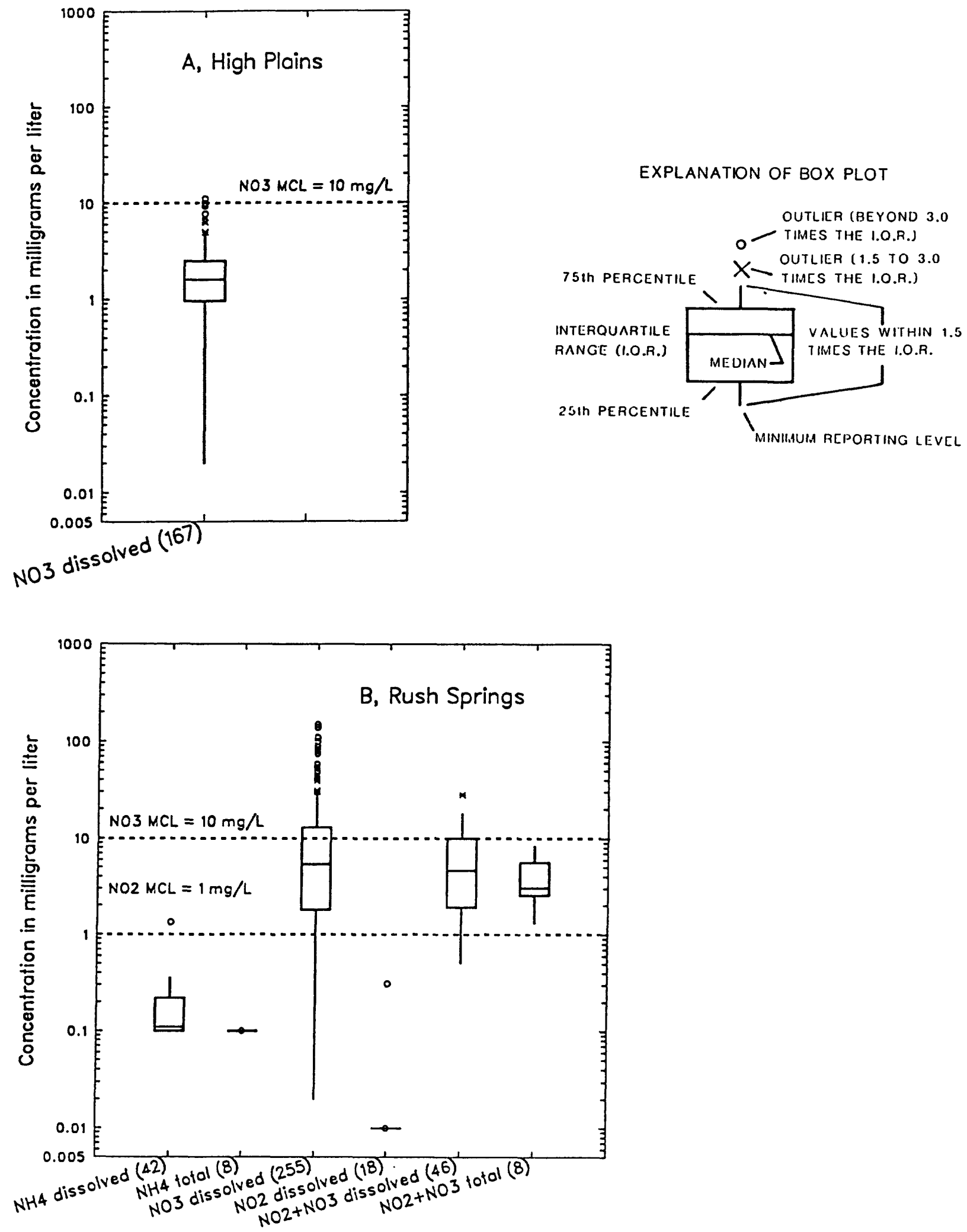

Figure 5.-Boxplots showing variability of nitrogen concentration in ground-water samples from bedrock aquifers: $A$, High Plains; B, Rush Springs; C, Blaine. All concentrations reported in $\mathrm{mg} / \mathrm{L}$ as nitrogen. Total number of samples in parentheses; $\mathrm{MCL}$, maximum contaminant level. 


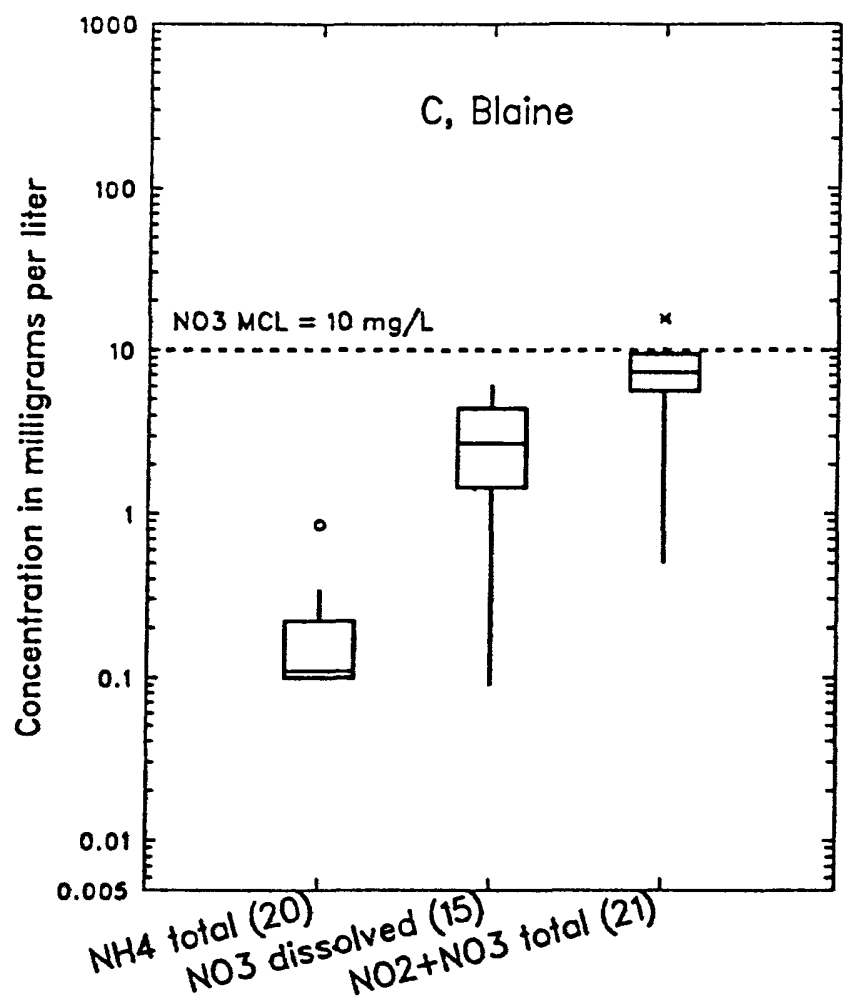

Figure 5 Boxplots showing variability of nitrogen concentration in ground-water samples from bedrock aquifers-Continued. 

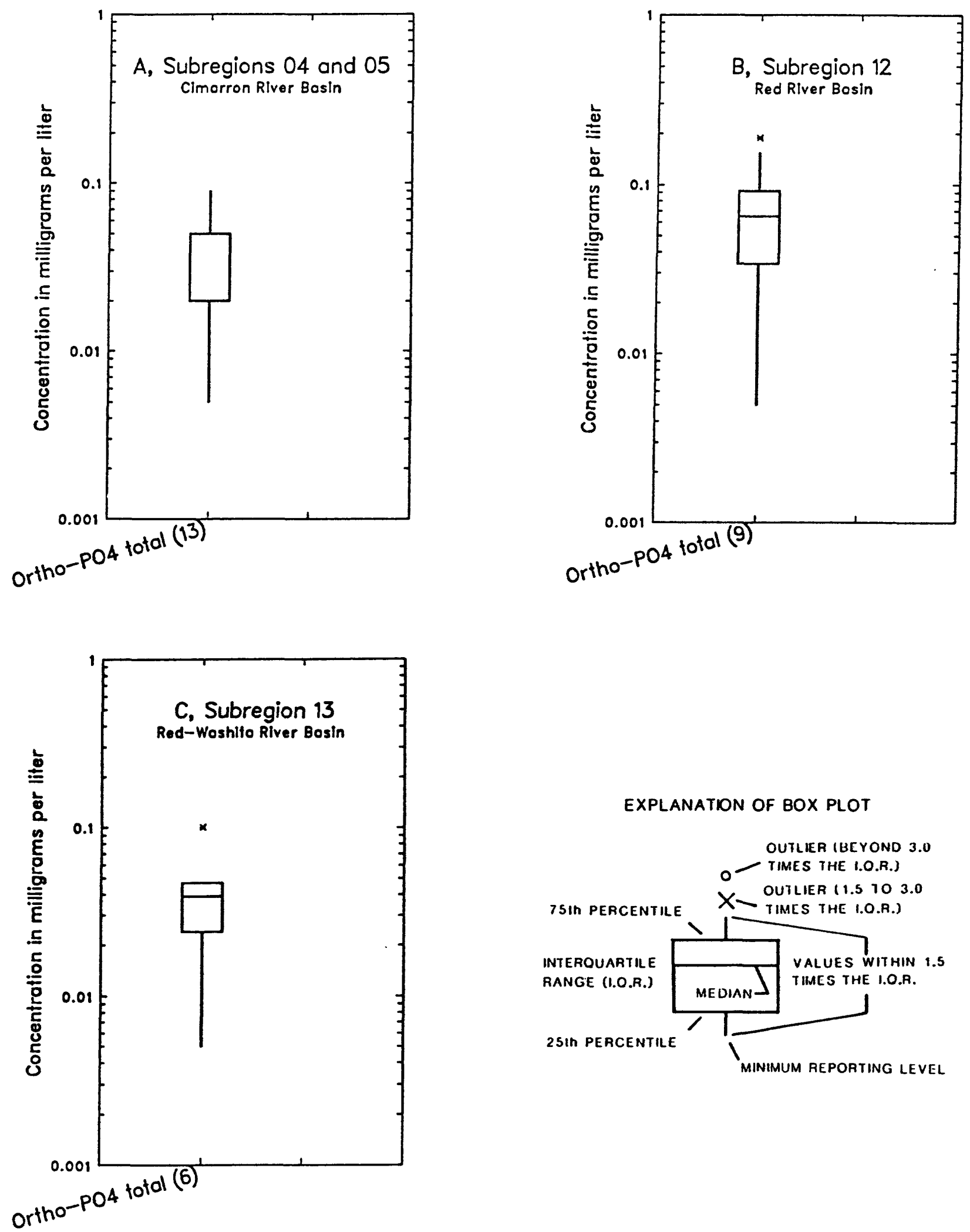

EXPLANATION OF BOX PLOT

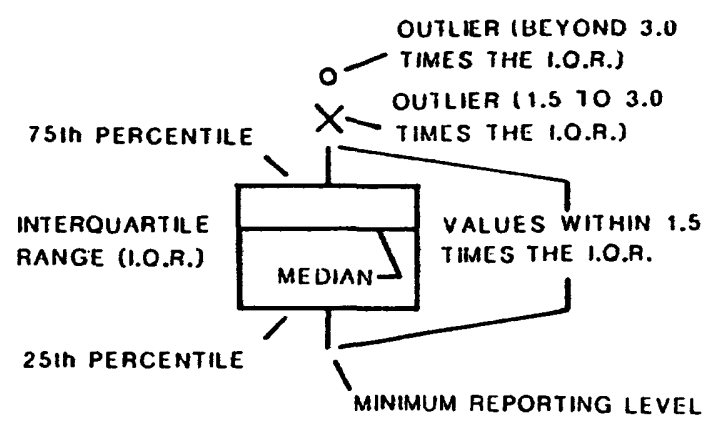

Figure 6.-Boxplots showing variability of phosphorus concentrations in ground-water samples from alluvial aquifers: A, Subregion 04 and 05, Cimarron River Basin; B, Subregion 12, Red River Basin; C, Subregion 13, Red-Washita River Basin. All concentrations reported in $\mathrm{mg} / \mathrm{L}$ as phosphorus. Total number of samples in parentheses. 

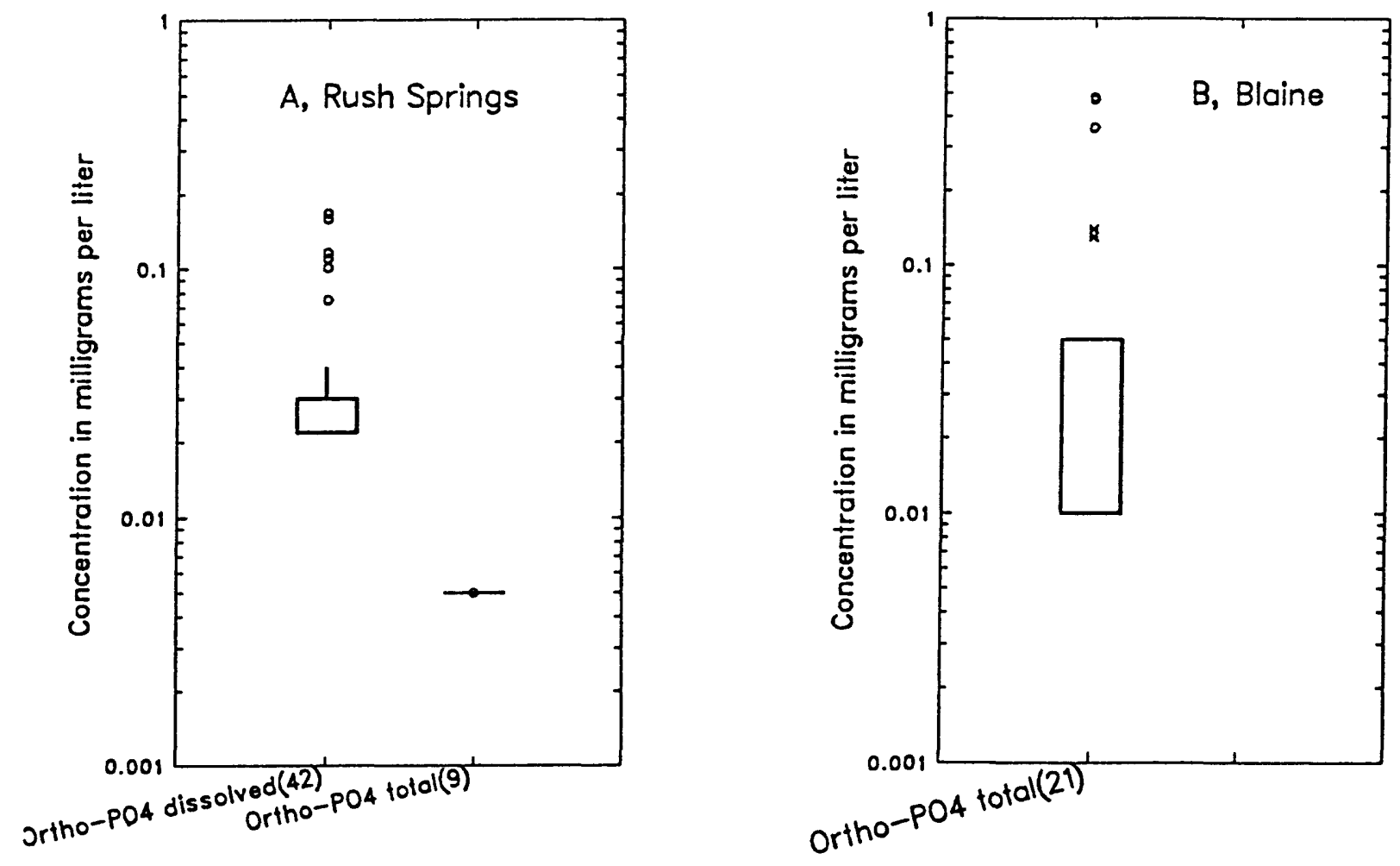

EXPLANATION OF BOX PLOT

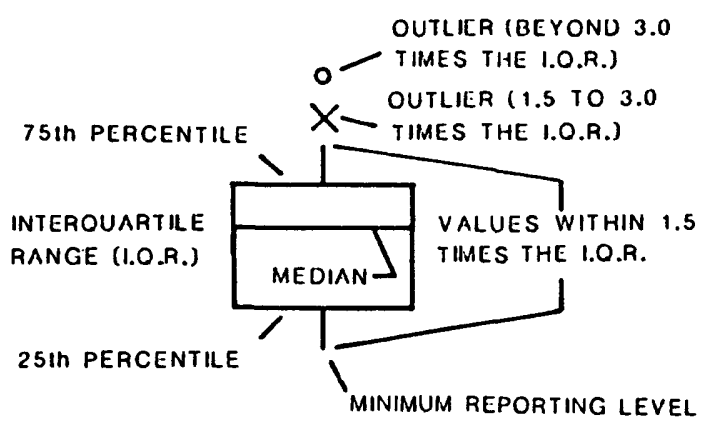

Figure 7.-Boxplots showing variability of phosphorus concentrations in ground-water samples from bedrock aquifers: A, Rush Springs; B, Blaine. All concentrations reported in $\mathrm{mg} / \mathrm{L}$ as phosphorus. Total number of samples in parentheses. 
Maps

Maps showing the areal distribution of wells where nutrient data are available were constructed for each aquifer (fig. 8-14). The bedrock aquifers are shown separately whereas the alluvial aquifers are shown together by hydrologic subregion on one map. Maps showing nitrogen and phosphorus data distribution are separate.

An open circle on the nitrogen map represents a well where $\mathrm{NH}_{4}$ was measured; $\mathrm{NO}_{3}$, or $\mathrm{NO}_{2}$
$+\mathrm{NO}_{3}$ was measured at concentrations of less than $10 \mathrm{mg} / \mathrm{L}$ as $\mathrm{N} ; \mathrm{NO}_{2}$ was measured at concentrations of less than $1.0 \mathrm{mg} / \mathrm{L}$ as $\mathrm{N}$; or where censored data were present. Sites are differentiated by a solid circle where the concentration of $\mathrm{NO}_{2}, \mathrm{NO}_{3}$, or $\mathrm{NO}_{2}+\mathrm{NO}_{3}$ exceed the MCL. Wells where phosphorus was measured are represented on the map by an open circle. No distinction is made between total and dissolved concentrations on the maps. 


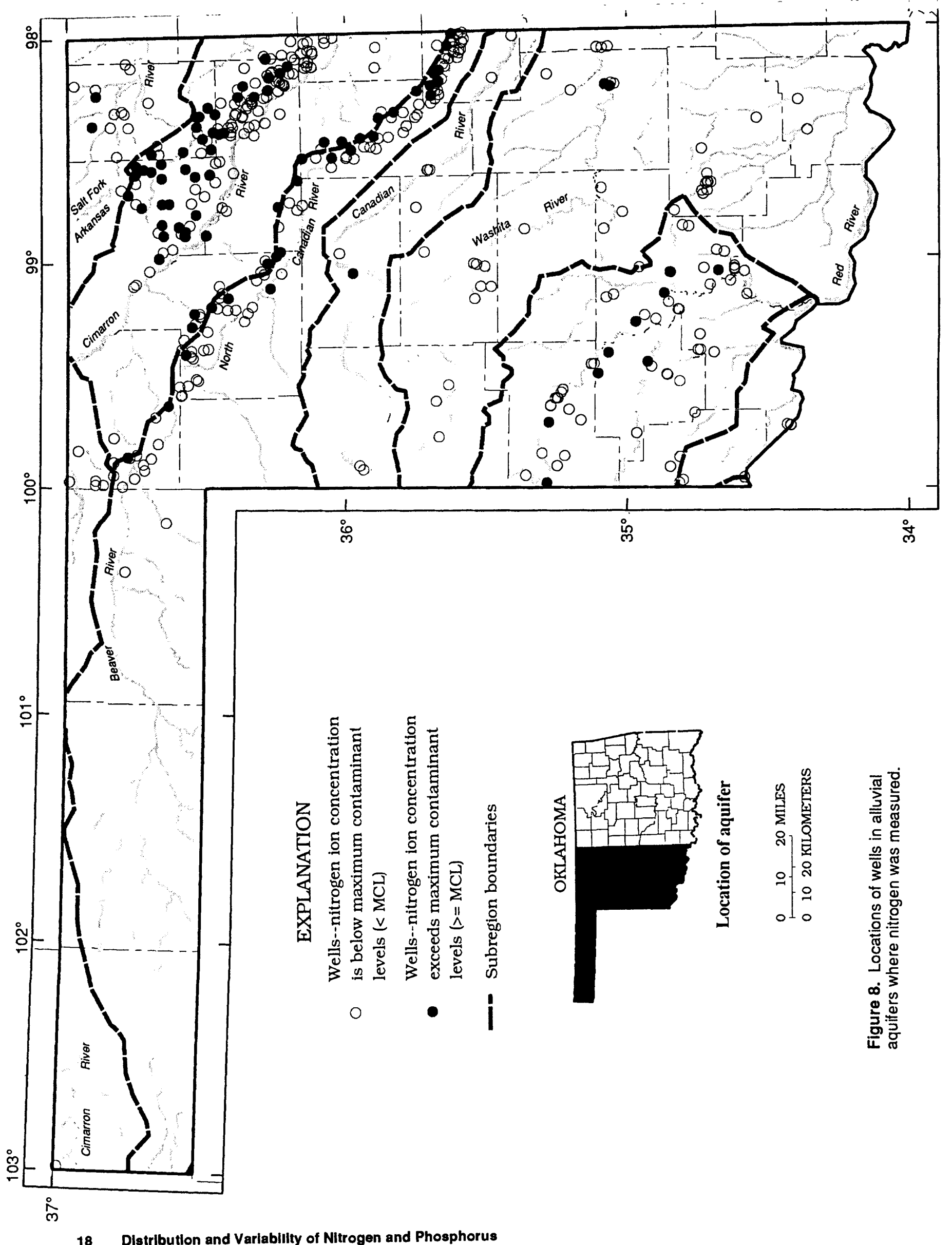




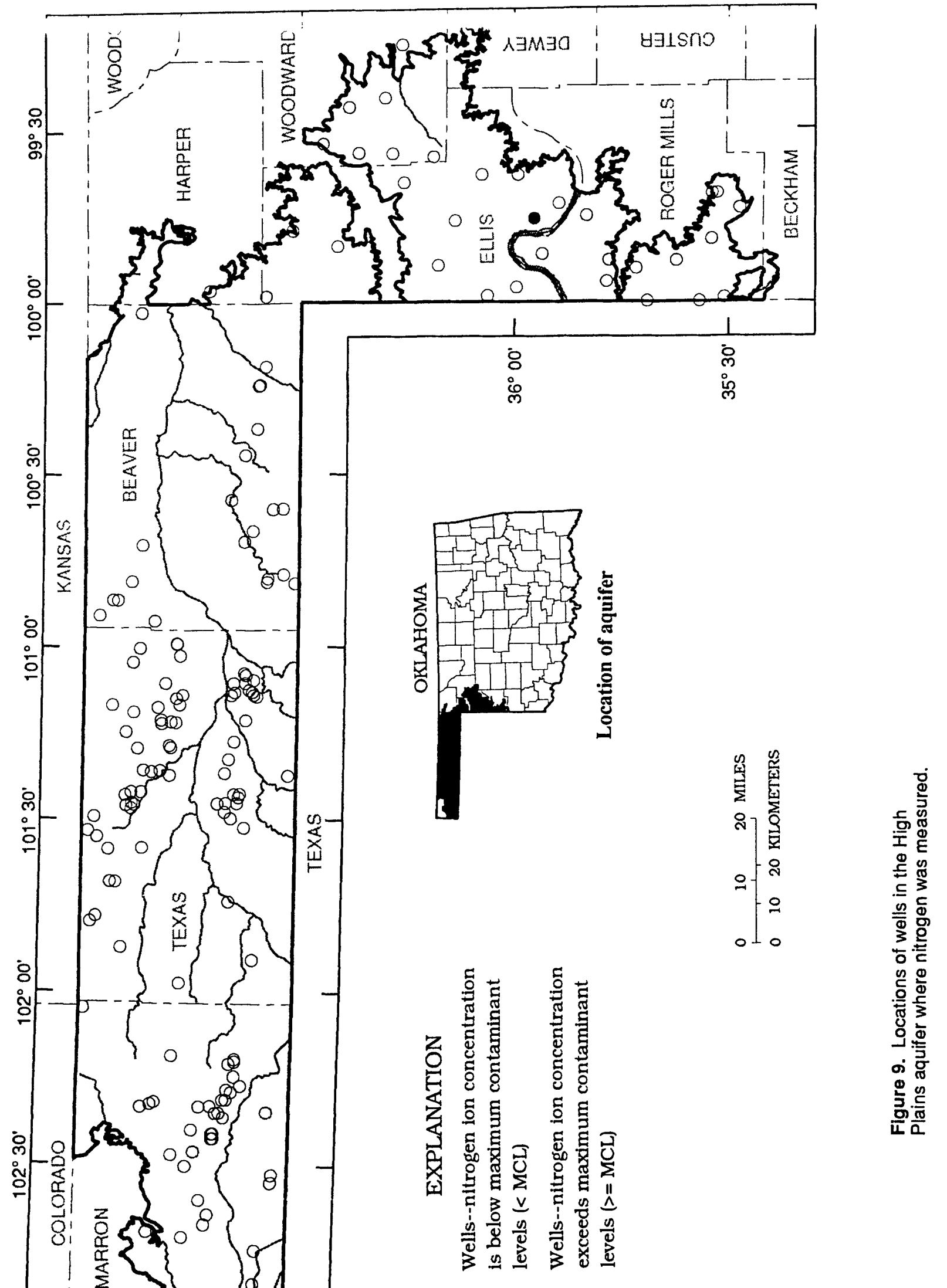

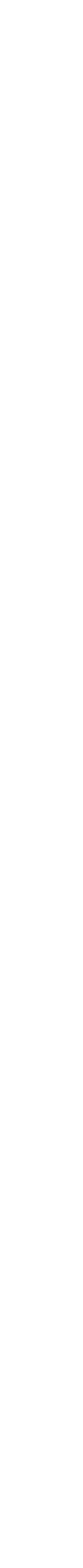

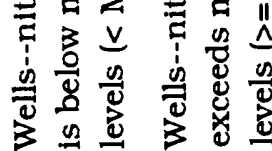

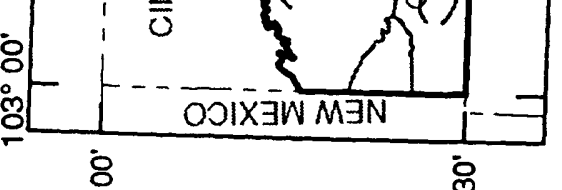

O 

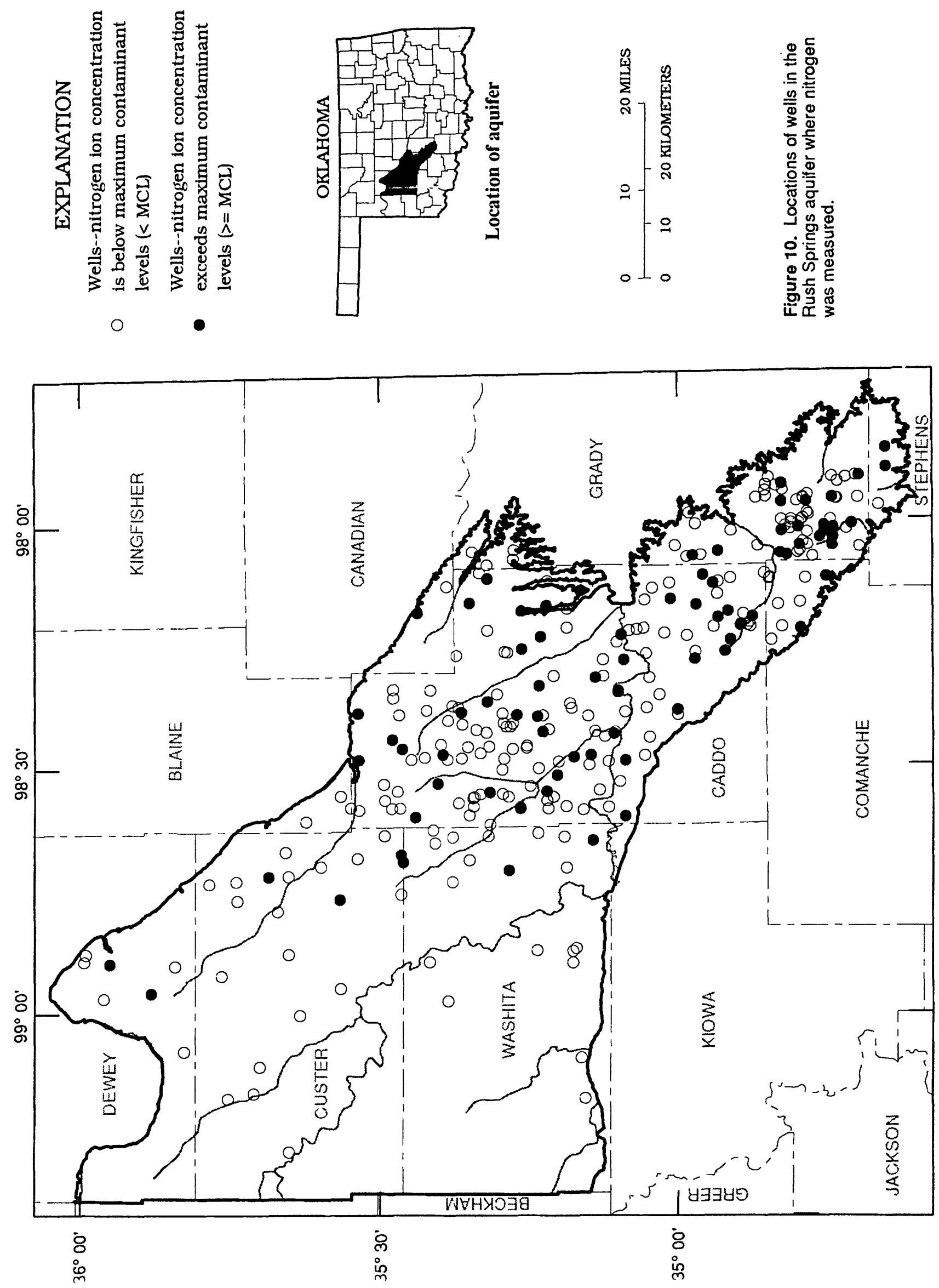

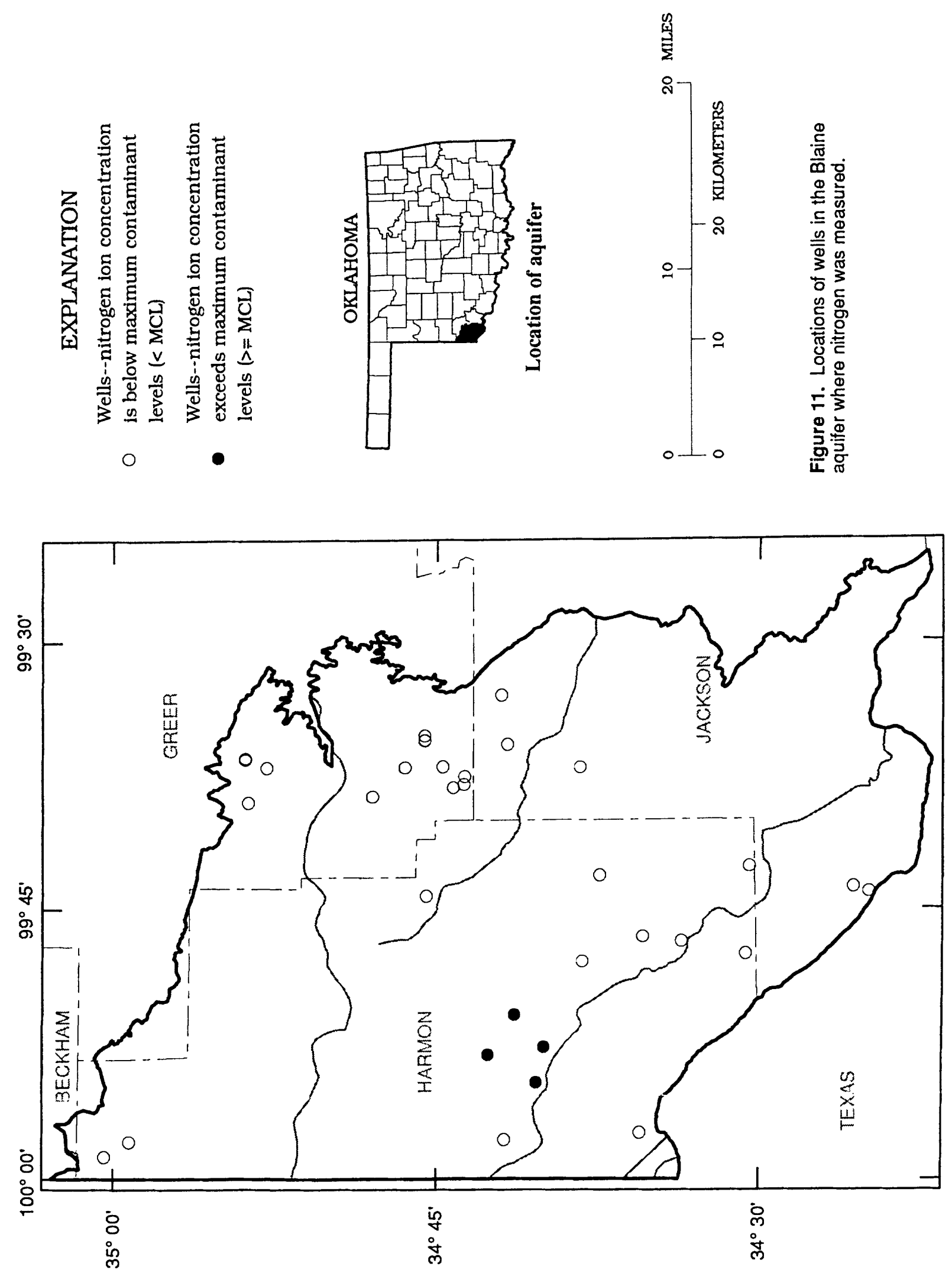


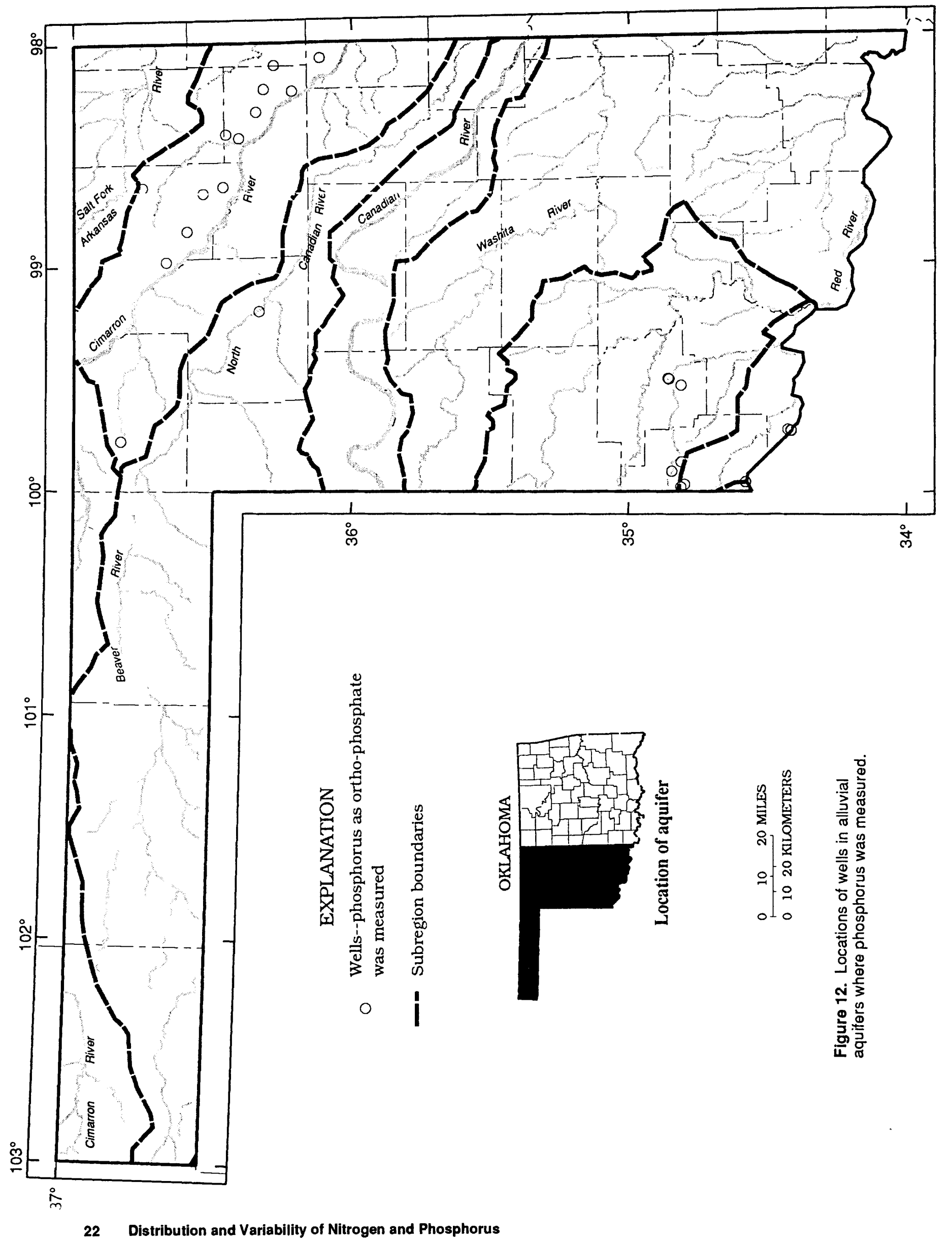




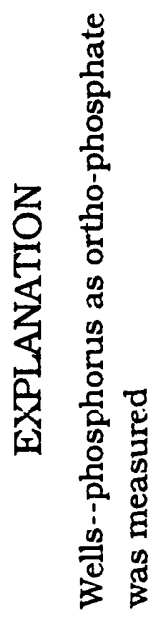

0
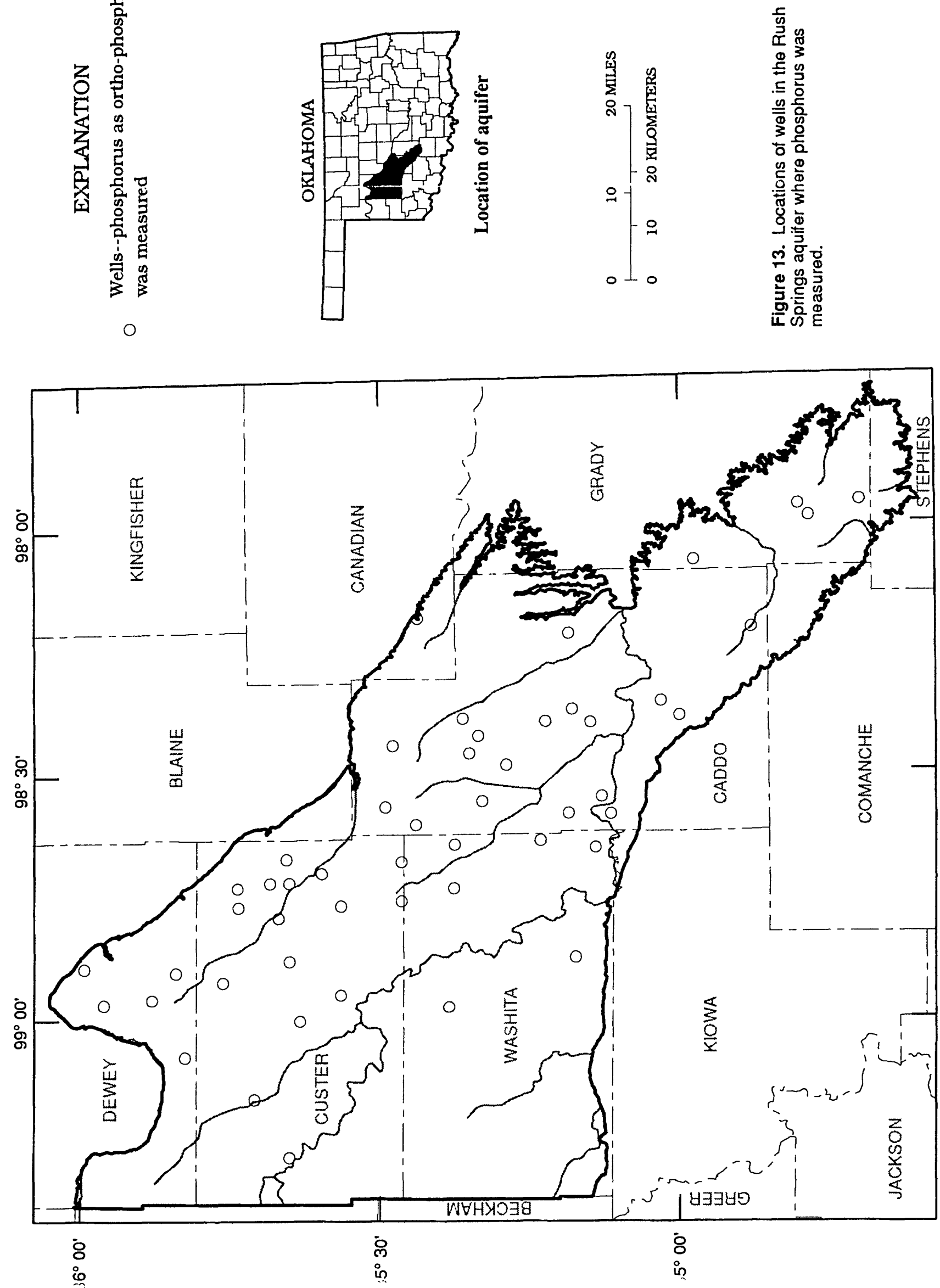

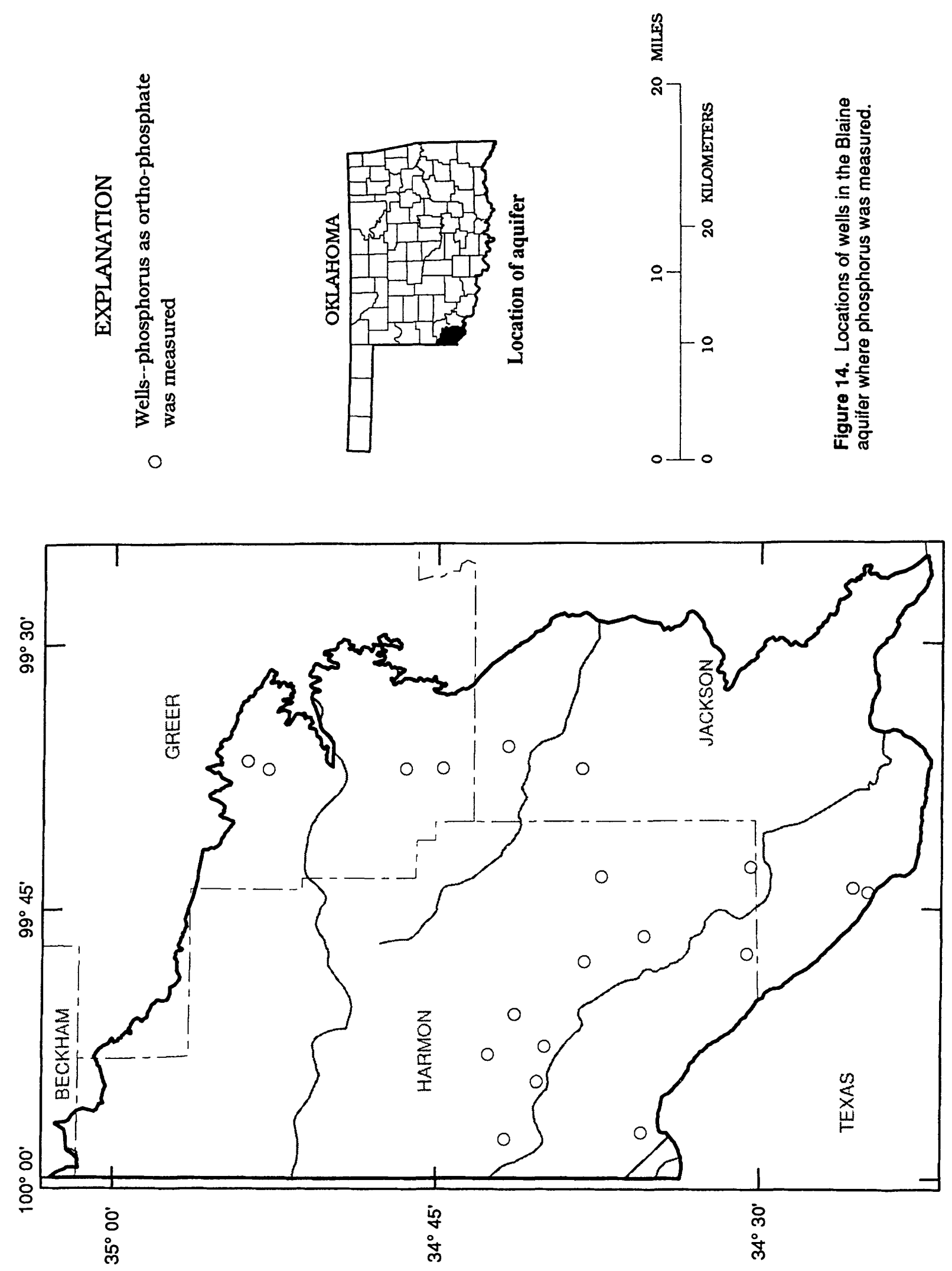


\section{Summary Statistics}

Statistical summaries of the available nutrient data for each aquifer and subregion are shown on tables 2 through 5. Shown are whether censored data were present, numbers of samples in each data set, largest MRL for each nutrient compound, percentiles used to construct boxplots, and minimum and maximum values. Also given are the number of wells sampled in each aquifer and the number of wells exceeding the MCL's. There are no percentiles shown for a nutrient compound if fewer than four analyses are present. 
Table 2. Nitrogen summary statistics for alluvial aquifers: A, Subregions 04 and 05; B, Subregion 06; C, Subregion 09; D, Subregion 10; E, Subregion 12, F, Subregion 13

[Calculated using most recent analyses for each nitrogen compound. All concentrations reported in $\mathrm{mg} / \mathrm{L}$ as nitrogen. MRL, largest minimum reporting level. Method: 1 , no censored data; 2 , censored data present; 3 , no calculation, less than four analyses available. --, no data]

A Summary statistics for nitrogen from the alluvial aquifers in subregions 04 and 05

\begin{tabular}{|c|c|c|c|c|c|c|c|c|c|c|c|c|}
\hline \multirow{2}{*}{$\begin{array}{l}\text { Nitrogen } \\
\text { lons }\end{array}$} & \multirow{2}{*}{ Method } & \multirow{2}{*}{$\begin{array}{c}\text { Data } \\
\text { set size }\end{array}$} & \multirow{2}{*}{$\begin{array}{c}\text { Largest } \\
\text { MRL }\end{array}$} & \multirow{2}{*}{$\begin{array}{c}\text { Min } \\
\text { value }\end{array}$} & \multicolumn{7}{|c|}{ Percentiles } & \multirow{2}{*}{$\begin{array}{c}\text { Max } \\
\text { value }\end{array}$} \\
\hline & & & & & 5 & 10 & 25 & 50 & 75 & 90 & 95 & \\
\hline $\mathrm{NH}_{4}$, dissolved & -- & -- & - & -- & -- & - & -- & - & -- & - & -- & $\overline{-}$ \\
\hline $\mathrm{NH}_{4}$, total & 3 & 1 & 0.1 & 0.16 & -- & - & -- & - & -- & -- & - & 0.16 \\
\hline $\mathrm{NO}_{3}$, dissolved & 2 & 113 & 0.02 & 0.02 & 0.11 & 0.30 & 200 & 5.60 & 12.50 & 29.60 & 5240 & 89.00 \\
\hline $\mathrm{NO}_{3}$, total & -- & -- & -- & -- & -- & -- & -- & -- & - & - & -- & -- \\
\hline $\mathrm{NO}_{2}$, dissolved & -- & -- & - & - & -- & - & - & - & - & - & - & -- \\
\hline $\mathrm{NO}_{2}$, total & -- & -- & - & - & -- & - & - & - & -- & -- & - & - \\
\hline $\mathrm{NO}_{2}+\mathrm{NO}_{3}$, dissolved & 1 & 7 & 0.1 & 4.20 & 4.20 & 4.20 & 6.50 & 9.40 & 14.00 & 15.00 & 15.00 & 15.00 \\
\hline $\mathrm{NO}_{2}+\mathrm{NO}_{3}$, total & 2 & 41 & 0.5 & 0.5 & 0.50 & 238 & 5.85 & 7.90 & 1290 & 15.30 & 33.66 & 53.90 \\
\hline
\end{tabular}

Total number of sites 161

Total number of sites exceeding MCL 50

B Summary statistics for nitrogen from the alluvial aquifers in subregion 06

\begin{tabular}{|c|c|c|c|c|c|c|c|c|c|c|c|c|}
\hline \multirow{2}{*}{$\begin{array}{l}\text { Nitrogen } \\
\text { lons }\end{array}$} & \multirow{2}{*}{ Method } & \multirow{2}{*}{$\begin{array}{c}\text { Data } \\
\text { set slze }\end{array}$} & \multirow{2}{*}{$\begin{array}{c}\text { Largest } \\
\text { MRL }\end{array}$} & \multirow{2}{*}{$\begin{array}{c}\text { Min } \\
\text { value }\end{array}$} & \multicolumn{7}{|c|}{ Percentiles } & \multirow{2}{*}{$\begin{array}{c}\text { Max } \\
\text { value }\end{array}$} \\
\hline & & & & & 5 & 10 & 25 & 50 & 75 & 90 & 95 & \\
\hline$\overline{\mathrm{NH}_{4}}$, dissolved & -- & -- & -- & -- & -- & - & - & - & 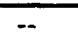 & -- & -- & $\overline{--}$ \\
\hline $\mathrm{NH}_{4}$, total &.- & -- & - & - & -- & - & $\ldots$ & -- & - & -- & -- & - \\
\hline $\mathrm{NO}_{3}$, dissolved & 2 & 16 & 0.02 & 0.02 & 0.02 & 0.02 & 0.68 & 250 & 5.65 & 12.00 & 12.00 & 12.00 \\
\hline $\mathrm{NO}_{3}$, total & -- & -- & -- & -- & -- & -- & -- & -- & -- & -- & -- & -- \\
\hline $\mathrm{NO}_{2}$, dissolved & -- & -- & -- & -. & -- & -. & - & -- & -. & - & - & - \\
\hline $\mathrm{NO}_{2}$, total & - & - & -- & -- & - & - & - & - & - & -. & -- & - \\
\hline $\mathrm{NO}_{2}+\mathrm{NO}_{3}$, dissolved & -- & -- & -- & -- & -- & - & -- & -- & - & -- & -- & -- \\
\hline $\mathrm{NO}_{2}+\mathrm{NO}_{3}$, total & - & -- & -- & - & -- & - & -- & -- & - & -- & - & -- \\
\hline
\end{tabular}

C Summary stauistics for nitrogen from the alluvial aquifers in subregion 09

\begin{tabular}{|c|c|c|c|c|c|c|c|c|c|c|c|c|}
\hline \multirow{2}{*}{$\begin{array}{l}\text { Nitrogen } \\
\text { Ions }\end{array}$} & \multirow{2}{*}{ Method } & \multirow{2}{*}{$\begin{array}{c}\text { Data } \\
\text { set slze }\end{array}$} & \multirow{2}{*}{$\begin{array}{c}\text { Largest } \\
\text { MRL }\end{array}$} & \multirow{2}{*}{$\underset{\text { value }}{\text { Min }}$} & \multicolumn{7}{|c|}{ Percentiles } & \multirow{2}{*}{$\begin{array}{c}\text { Max } \\
\text { value }\end{array}$} \\
\hline & & & & & 5 & 10 & 25 & 50 & 75 & 90 & 95 & \\
\hline $\mathrm{NH}_{4}$, dissolved & - & - & - & $\cdots$ & - & - & - & -- & - & - & - & -- \\
\hline $\mathrm{NH}_{4}$, total & -- & -- & -- & - & -- & -- & - & -- & - & -- & -- & - \\
\hline $\mathrm{NO}_{3}$, dissolved & 2 & 12 & 0.02 & 0.02 & 0.02 & 0.03 & 0.07 & 0.90 & 5.00 & 23.27 & 29.00 & 29.00 \\
\hline $\mathrm{NO}_{3}$, total & -- & -. & -- & -- & -- & -- & - & -- & - & -- & -- & -- \\
\hline $\mathrm{NO}_{2}$, dissolved & - & -- & -- & - & - & -- & - & - & - & -- & -- & -- \\
\hline $\mathrm{NO}_{2}$, total & -- & - & -- & -- & -- & -- & -- & -- & -- & -- & - & -- \\
\hline $\mathrm{NO}_{2}+\mathrm{NO}_{3}$, dissolved & -- & -- & -- & -- & -- & -- & -- & - & -- & -- & - & -- \\
\hline $\mathrm{NO}_{2}+\mathrm{NO}_{3}$, total & - & -- & -- & -- & - & -- & $\cdots$ & - & -- & - & -- & -- \\
\hline
\end{tabular}


Table 2. Nitrogen summary statistics for alluvial aquifers-Continued

D Summary statistics for nitrogen from the alluvial aquifers in subregion 10

\begin{tabular}{|c|c|c|c|c|c|c|c|c|c|c|c|c|}
\hline \multirow{2}{*}{$\begin{array}{l}\text { Nitrogen } \\
\text { lons }\end{array}$} & \multirow{2}{*}{ Method } & \multirow{2}{*}{$\begin{array}{c}\text { Data } \\
\text { set size }\end{array}$} & \multirow{2}{*}{$\begin{array}{l}\text { Largest } \\
\text { MRL }\end{array}$} & \multirow{2}{*}{$\underset{\text { value }}{\text { Min }}$} & \multicolumn{7}{|c|}{ Percentiles } & \multirow{2}{*}{$\begin{array}{l}\text { Max } \\
\text { value }\end{array}$} \\
\hline & & & & & 5 & 10 & 25 & 50 & 75 & 90 & 95 & \\
\hline $\mathrm{NH}_{4}$, dissolved & -- & -- & -- & - & - & $\overline{--}$ & - & - & -- & -- & - & -- \\
\hline $\mathrm{NH}_{4}$, total & 3 & 1 & 0.1 & 0.19 & -. & -- & -- & - & -- & -- & -- & 0.19 \\
\hline $\mathrm{NO}_{3}$, dissolved & 2 & 69 & 0.02 & 0.02 & 0.02 & 0.09 & 0.33 & 220 & 6.20 & 11.00 & 18.50 & 55.00 \\
\hline $\mathrm{NO}_{3}$, total & -- & -- & -- & - & -- & -- & -- & -- & -- & -- & -- & - \\
\hline $\mathrm{NO}_{2}$, dissolved & -. & -- & -- & -- & -- & -- & -- & -- & -- & - & -- & -- \\
\hline $\mathrm{NO}_{2}$, total & -- & -- & -- & -- & -- & -- & -- & -- & -- & -- & -- & -- \\
\hline $\mathrm{NO}_{2}+\mathrm{NO}_{3}$, dissolved & 2 & 49 & 0.1 & 0.1 & 0.10 & 0.12 & 275 & 6.50 & 12.00 & 28.00 & 34.50 & 46.00 \\
\hline $\mathrm{NO}_{2}+\mathrm{NO}_{3}$, total & 3 & 1 & 0.1 & 7.40 & -- & - & - & - & - & -- & - & 7.40 \\
\hline
\end{tabular}

Total number of sites 119

Total number of sites exceeding MCL 25

E Summary statistics for nitrogen from the alluvial aquifers subregion 12

\begin{tabular}{|c|c|c|c|c|c|c|c|c|c|c|c|c|}
\hline \multirow{2}{*}{$\begin{array}{l}\text { Nltrogen } \\
\text { Ions }\end{array}$} & \multirow{2}{*}{ Method } & \multirow{2}{*}{$\begin{array}{c}\text { Data } \\
\text { set size }\end{array}$} & \multirow{2}{*}{$\begin{array}{c}\text { Largest } \\
\text { MRL }\end{array}$} & \multirow{2}{*}{$\begin{array}{c}\text { Mln } \\
\text { value }\end{array}$} & \multicolumn{7}{|c|}{ Percentlles } & \multirow{2}{*}{$\begin{array}{c}\text { Max } \\
\text { value }\end{array}$} \\
\hline & & & & & 5 & 10 & 25 & 50 & 75 & 90 & 95 & \\
\hline$\overline{\mathrm{NH}_{4}, \text { dissolved }}$ & - & -- & -- & - & -- & - & -- & -- & 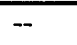 & $-\infty$ & $\cdots$ & -- \\
\hline $\mathrm{NH}_{4}$, total & 2 & 9 & 0.1 & 0.1 & 0.10 & 0.10 & 0.10 & 0.1 & 0.17 & 0.33 & 0.33 & 0.33 \\
\hline $\mathrm{NO}_{3}$, dissolved & 1 & 60 & 0.02 & 0.02 & 0.05 & 0.11 & 0.78 & 4.05 & 6.95 & 15.90 & 28.50 & 68.00 \\
\hline $\mathrm{NO}_{3}$, total & -- & -- & - & -- & -- & -- & -- & -- & -- & -- & - & -- \\
\hline $\mathrm{NO}_{2}$, dissolved & -- & -- & -- & - & -- & -- & -- & -- & -- & -- & -- & -- \\
\hline $\mathrm{NO}_{2}$, total & - & -- & - & -- & -- & - & - & - & - & -- & - & -- \\
\hline $\mathrm{NO}_{2}+\mathrm{NO}_{3}$, dissolved & -- & -- & -- & - & -- & - & -- & -- & - & - & -- & -- \\
\hline $\mathrm{NO}_{2}+\mathrm{NO}_{3}$, total & 2 & 9 & 0.50 & 0.50 & 0.50 & 0.50 & 0.50 & 0.50 & 5.45 & 8.70 & 8.70 & 8.70 \\
\hline
\end{tabular}

Total number of sites 69

Total number of sites exceeding MCL 9

F Summary statistics for nitrogen from the alluvial aquifers in subregion 13

\begin{tabular}{|c|c|c|c|c|c|c|c|c|c|c|c|c|}
\hline \multirow{2}{*}{$\begin{array}{l}\text { Nitrogen } \\
\text { lons }\end{array}$} & \multirow{2}{*}{ Method } & \multirow{2}{*}{$\begin{array}{c}\text { Data } \\
\text { set size }\end{array}$} & \multirow{2}{*}{$\begin{array}{l}\text { Largest } \\
\text { MCL }\end{array}$} & \multirow{2}{*}{$\begin{array}{c}\text { Min } \\
\text { value }\end{array}$} & \multicolumn{7}{|c|}{ Percentles } & \multirow{2}{*}{$\begin{array}{l}\text { Max } \\
\text { value }\end{array}$} \\
\hline & & & & & 5 & 10 & 25 & 50 & 75 & 90 & 95 & \\
\hline $\mathrm{NH}_{4}$, dissolved & -- & -- & - & -- & - & - & $\overline{-}$ & - & 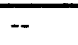 & -- & $\overline{--}$ & - \\
\hline $\mathrm{NH}_{4}$, total & 2 & 6 & 0.1 & 0.1 & 0.10 & 0.10 & 0.10 & 0.11 & 0.38 & 0.85 & 0.85 & 0.85 \\
\hline NO3, dissolved & 2 & 34 & 0.02 & 0.02 & 0.02 & 0.04 & 0.13 & 0.42 & 3.47 & 9.90 & 12.75 & 18.00 \\
\hline $\mathrm{NO}_{3}$, total & - & -- & -- & -- & -- & - & -- & -- & -- & -- & -- & -- \\
\hline $\mathrm{NO}_{2}$, dissolved & -- & -- & -- & -- & -- & - & - & -- & - & -- & -- & -- \\
\hline $\mathrm{NO}_{2}$, total & -- & -- & -- & -- & -- & - & -- & - & -- & -- & -- & -- \\
\hline $\mathrm{NO}_{2}+\mathrm{NO}_{3}$, dissolved & - & -- & -- & -- & -- & - & - & -- & - & -- & -- & -- \\
\hline $\mathrm{NO}_{2}+\mathrm{NO}_{3}$, total & 2 & 6 & 0.5 & 0.5 & 0.50 & 0.50 & 0.50 & 0.85 & 3.57 & 9.50 & 9.50 & 9.50 \\
\hline
\end{tabular}

Total number of sites 40

Total number of sites exceeding MCL 2 
Table 3. Nitrogen summary statistics for bedrock aquifers: A, High Plains; B, Rush Springs; C, Blaine [Calculated using most recent analyses for each nitrogen compound. All concentrations reported in $\mathrm{mg} / \mathrm{L}$ as nitrogen. MRL, largest reporting level. Method: 1 , no censored data; 2 , censored data present; 3 , no calculation, less than four analyses available. --, no data]

A Summary statistics for nitrogen in the High Plains aquifer

\begin{tabular}{|c|c|c|c|c|c|c|c|c|c|c|c|c|}
\hline \multirow{2}{*}{$\begin{array}{c}\text { Nitrogen } \\
\text { Ions }\end{array}$} & \multirow{2}{*}{ Method } & \multirow{2}{*}{$\begin{array}{c}\text { Data } \\
\text { set size }\end{array}$} & \multirow{2}{*}{$\begin{array}{c}\text { Largest } \\
\text { MRL }\end{array}$} & \multirow{2}{*}{$\underset{\text { Malue }}{\text { Min }}$} & \multicolumn{7}{|c|}{ Percentlles } & \multirow{2}{*}{$\begin{array}{l}\text { Max } \\
\text { value }\end{array}$} \\
\hline & & & & & 5 & 10 & 25 & 50 & 75 & 90 & 95 & \\
\hline $\mathrm{NH}_{4}$, dissolved & -- & -- & - & - & $\overline{--}$ & $\overline{--}$ & -- & -- & - & -- & -- & -- \\
\hline $\mathrm{NH}_{4}$, total & 3 & 1 & 0.02 & 0.23 & -- & -- & -- & - & -- & - & -- & 0.23 \\
\hline $\mathrm{NO}_{3}$, dissolved & 2 & 167 & 0.02 & 0.02 & 0.05 & 0.18 & 0.95 & 1.60 & 250 & 4.34 & 5.78 & 11.00 \\
\hline $\mathrm{NO}_{3}$, total & -- & - & - & - & - & -- & -- & $\cdots$ & - & - & -- & - \\
\hline $\mathrm{NO}_{2}$, dissolved & -- & -- & -- & - & -- & -- & -- & -- & - & -- & - & -- \\
\hline $\mathrm{NO}_{2}$, total & -- & -- & -- & - & -- & -- & - & -- & -- & - & - & - \\
\hline $\mathrm{NO}_{2}+\mathrm{NO}_{3}$, dissolved & -- & -- & -- & - & -- & -- & - & - & -- & -. & -- & -- \\
\hline $\mathrm{NO}_{2}+\mathrm{NO}_{3}$, total & 3 & 1 & 0.5 & 1.20 & -- & -- & -- & -- & -- & -- & -. & 1.20 \\
\hline
\end{tabular}

B Summary statistics for nitrogen in the Rush Springs aquifer

\begin{tabular}{|c|c|c|c|c|c|c|c|c|c|c|c|c|}
\hline \multirow{2}{*}{$\begin{array}{c}\text { Nitrogen } \\
\text { lons }\end{array}$} & \multirow{2}{*}{ Method } & \multirow{2}{*}{$\begin{array}{c}\text { Data } \\
\text { set size }\end{array}$} & \multirow{2}{*}{$\begin{array}{c}\text { Largest } \\
\text { MRL }\end{array}$} & \multirow{2}{*}{$\begin{array}{c}\text { Min } \\
\text { value }\end{array}$} & \multicolumn{7}{|c|}{ Percentiles } & \multirow{2}{*}{$\begin{array}{l}\text { Max } \\
\text { value }\end{array}$} \\
\hline & & & & & 5 & 10 & 25 & 50 & 75 & 90 & 95 & \\
\hline $\mathrm{NH}_{4}$, dissolved & 2 & 42 & 0.1 & 0.10 & 0.10 & 0.10 & 0.10 & 0.11 & 0.22 & 0.23 & 0.35 & 1.34 \\
\hline $\mathrm{NH}_{4}$, total & 2 & 8 & 0.1 & 0.10 & 0.10 & 0.10 & 0.10 & 0.10 & 0.10 & 0.10 & 0.10 & 0.10 \\
\hline $\mathrm{NO}_{3}$, dissolved & 2 & 255 & 0.02 & 0.02 & 0.22 & 0.45 & 1.80 & 5.40 & 13.00 & 29.40 & 53.20 & 150.00 \\
\hline $\mathrm{NO}_{3}$, total & -- & -- & - & -- & -- & -- & -- & -- & -- & -. & -- & -- \\
\hline $\mathrm{NO}_{2}$, dissolved & 2 & 18 & 0.01 & 0.01 & 0.01 & 0.01 & 0.01 & 0.01 & 0.01 & 0.04 & 0.31 & 0.31 \\
\hline $\mathrm{NO}_{2}$, total & -- & -- & -- & - & - & -- & - & -- & -- & -- & - & -- \\
\hline $\mathrm{NO}_{2}+\mathrm{NO}_{3}$, dissolved & 2 & 46 & 0.5 & 0.50 & 0.50 & 0.70 & 1.87 & 4.65 & 10.00 & 12.65 & 17.47 & 28.00 \\
\hline $\mathrm{NO}_{2}+\mathrm{NO}_{3}$, total & 1 & 8 & 0.1 & 1.30 & 1.30 & 1.30 & 237 & 3.05 & 5.92 & 8.40 & 8.40 & 8.40 \\
\hline
\end{tabular}

Total number of sites 313

Total number of sites exceeding MCL 91

C Summary statistics for nitrogen in the Blaine aquifer

\begin{tabular}{|c|c|c|c|c|c|c|c|c|c|c|c|c|}
\hline \multirow{2}{*}{$\begin{array}{l}\text { Nitrogen } \\
\text { ions }\end{array}$} & \multirow{2}{*}{ Mothod } & \multirow{2}{*}{$\begin{array}{l}\text { Data } \\
\text { set size }\end{array}$} & \multirow{2}{*}{$\begin{array}{l}\text { Largest } \\
\text { MRL }\end{array}$} & \multirow{2}{*}{$\begin{array}{l}\text { Min } \\
\text { value }\end{array}$} & \multicolumn{7}{|c|}{ Percentiles } & \multirow{2}{*}{$\begin{array}{l}\text { Max } \\
\text { value }\end{array}$} \\
\hline & & & & & 5 & 10 & 25 & 50 & 75 & 90 & 95 & \\
\hline$\overline{\mathrm{NH}_{4} \text {, dissolved }}$ & $\overline{--}$ & -- & - & $\overline{-}$ & $\overline{--}$ & -- & $\overline{--}$ & - & -- & -- & $\overline{--}$ & - \\
\hline $\mathrm{NH}_{4}$, total & 2 & 21 & 0.1 & 0.10 & 0.10 & 0.10 & 0.10 & 0.11 & 0.22 & 0.34 & 0.82 & 0.85 \\
\hline $\mathrm{NO}_{3}$, dissolved & 1 & 15 & 0.02 & 0.09 & 0.09 & 0.52 & 1.10 & 2.70 & 4.50 & 5.26 & 6.10 & 6.10 \\
\hline $\mathrm{NO}_{3}$, total & 3 & 1 & 0.02 & 9.39 & - & -- & - & -- & -- & -- & -- & 9.39 \\
\hline $\mathrm{NO}_{2}$, dissolved & -- & -- & - & - & -- & -- & -- & -- & -- & -- & -- & - \\
\hline $\mathrm{NO}_{2}$, total & 3 & 3 & 0.01 & 0.01 & - & -- & - & -- & -- & -- & -- & 0.01 \\
\hline $\mathrm{NO}_{2}+\mathrm{NO}_{3}$, dissolved & -- & -- & -- & -- & -- & - & -- & - & -- & -- & -- & -- \\
\hline $\mathrm{NO}_{2}+\mathrm{NO}_{3}$, total & 2 & 21 & 0.5 & 0.50 & 0.50 & 0.50 & 4.85 & 7.00 & 9.45 & 10.44 & 15.10 & 15.60 \\
\hline
\end{tabular}

Total number of sites 35

Total number of sites exceeding MCL 4 
Table 4. Phosphorus summary statistics for alluvial aquifers: A, Subregions 04 and 05; B, Subregion 12; C, Subregion 13

[Calculated using most recent analyses. All concentrations reported in $\mathrm{mg} / \mathrm{L}$ as phosphorus. MRL, largest minimum reporting level.

Method: 1, no censored data; 2 , censored data present; 3, no calculation, less than four analyses available. --, no data]

A Summary statistics for phosphorus in the alluvial aquifers in subregions 04 and 05

\begin{tabular}{|c|c|c|c|c|c|c|c|c|c|c|c|c|}
\hline \multirow{2}{*}{$\begin{array}{l}\text { Phosphorus } \\
\text { Ions }\end{array}$} & \multirow{2}{*}{ Method } & \multirow{2}{*}{$\begin{array}{c}\text { Sample } \\
\text { size }\end{array}$} & \multirow{2}{*}{$\begin{array}{c}\text { Largest } \\
\text { MRL }\end{array}$} & \multirow{2}{*}{$\begin{array}{c}\text { Min } \\
\text { value }\end{array}$} & \multicolumn{7}{|c|}{ Percentiles } & \multirow{2}{*}{$\begin{array}{c}\text { Max } \\
\text { value }\end{array}$} \\
\hline & & & & & 5 & 10 & 25 & 50 & 75 & 90 & 95 & \\
\hline ortho- $\mathrm{PO}_{4}$, dissolved & -- & -- & -- & -- & -- & -- & -- & -- & -- & $\overline{--}$ & $\overline{--}$ & $\overline{-}$ \\
\hline ortho- $\mathrm{PO}_{4}$, total & 2 & 13 & 0.005 & 0.005 & 0.005 & 0.007 & 0.02 & 0.02 & 0.05 & 0.074 & 0.09 & 0.09 \\
\hline
\end{tabular}

B Summary statistics for phosphorus in the alluvial aquifers in subregion 12

\begin{tabular}{|c|c|c|c|c|c|c|c|c|c|c|c|c|}
\hline \multirow{2}{*}{$\begin{array}{c}\text { Phosphorus } \\
\text { lons }\end{array}$} & \multirow{2}{*}{ Method } & \multirow{2}{*}{$\begin{array}{c}\text { Sample } \\
\text { size }\end{array}$} & \multirow{2}{*}{$\begin{array}{c}\text { Largest } \\
\text { MRL }\end{array}$} & \multirow{2}{*}{$\underset{\substack{\text { Min } \\
\text { value }}}{\text { Min }}$} & \multicolumn{7}{|c|}{ Percentiles } & \multirow{2}{*}{$\begin{array}{c}\text { Max } \\
\text { value }\end{array}$} \\
\hline & & & & & 5 & 10 & 25 & 50 & 75 & 90 & 95 & \\
\hline ortho- $\mathrm{PO}_{4}$, dissolved & - & -- & $\overline{--}$ & -- & -- & $\overline{--}$ & -- & -- & -- & -- & - & - \\
\hline ortho- $\mathrm{PO}_{4}$, total & 2 & 9 & 0.005 & 0.005 & 0.005 & 0.005 & 0.026 & 0.065 & 0.123 & 0.189 & 0.189 & 0.189 \\
\hline
\end{tabular}

C Summary statistics for phosphorus in the alluvial aquifers in subregion 13

\begin{tabular}{|c|c|c|c|c|c|c|c|c|c|c|c|c|}
\hline \multirow{2}{*}{$\begin{array}{c}\text { Phosphorus } \\
\text { Ions }\end{array}$} & \multirow{2}{*}{ Method } & \multirow{2}{*}{$\begin{array}{l}\text { Sample } \\
\text { size }\end{array}$} & \multirow{2}{*}{$\begin{array}{l}\text { Largest } \\
\text { MRL }\end{array}$} & \multirow{2}{*}{$\begin{array}{c}\text { Min } \\
\text { value }\end{array}$} & \multicolumn{7}{|c|}{ Percentlles } & \multirow{2}{*}{$\begin{array}{c}\text { Max } \\
\text { value }\end{array}$} \\
\hline & & & & & 5 & 10 & 25 & 50 & 75 & 90 & 95 & \\
\hline ortho- $\mathrm{PO}_{4}$, dissolved & $\overline{--}$ & -- & $\overline{--}$ & - & $\overline{--}$ & $\overline{--}$ & - & -- & -- & -- & - & -- \\
\hline ortho- $\mathrm{PO}_{4}$, total & 2 & 6 & 0.005 & 0.005 & 0.005 & 0.005 & 0.019 & 0.039 & 0.060 & 0.101 & 0.101 & 0.101 \\
\hline
\end{tabular}

Table 5. Phosphorus summary statistics for bedrock aquifers: A, Rush Springs; B, Blaine

[Calculated using most recent analyses. All concentrations reported in $\mathrm{mg} / \mathrm{L}$ as phosphorus. $\mathrm{MRL}$, largest minimum reporting level.

Method: 1 , no censored data; 2 , censored data present; 3, no calculation, less than four analyses available. --, no data]

\section{A Summary statistics for phosphorus in the Rush Springs aquifer}

\begin{tabular}{|c|c|c|c|c|c|c|c|c|c|c|c|c|}
\hline \multirow{2}{*}{$\begin{array}{c}\text { Phosphorus } \\
\text { lons }\end{array}$} & \multirow{2}{*}{ Method } & \multirow{2}{*}{$\begin{array}{c}\text { Sample } \\
\text { size }\end{array}$} & \multirow{2}{*}{$\begin{array}{l}\text { Largest } \\
\text { MRL }\end{array}$} & \multirow{2}{*}{$\begin{array}{l}\text { Min } \\
\text { value }\end{array}$} & \multicolumn{7}{|c|}{ Percentiles } & \multirow{2}{*}{$\begin{array}{c}\text { Max } \\
\text { value }\end{array}$} \\
\hline & & & & & 5 & 10 & 25 & 50 & 75 & 90 & 95 & \\
\hline ortho- $\mathrm{PO}_{4}$, dissolved & 2 & 42 & 0.005 & 0.010 & 0.010 & 0.010 & 0.010 & 0.012 & 0.030 & 0.107 & 0.153 & 0.168 \\
\hline ortho- $\mathrm{PO}_{4}$, total & 2 & 9 & 0.005 & 0.005 & 0.005 & 0.005 & 0.005 & 0.005 & 0.005 & 0.005 & 0.005 & 0.005 \\
\hline
\end{tabular}

B Summary statistics for phosphorus in the Blaine aquifer

\begin{tabular}{|c|c|c|c|c|c|c|c|c|c|c|c|c|}
\hline \multirow{2}{*}{$\begin{array}{l}\text { Phosphorus } \\
\text { ions }\end{array}$} & \multirow{2}{*}{ Method } & \multirow{2}{*}{$\begin{array}{c}\text { Sample } \\
\text { size }\end{array}$} & \multirow{2}{*}{$\begin{array}{l}\text { Largest } \\
\text { MRL }\end{array}$} & \multirow{2}{*}{$\begin{array}{c}\text { Min } \\
\text { value }\end{array}$} & \multicolumn{7}{|c|}{ Percentles } & \multirow{2}{*}{$\begin{array}{l}\text { Max } \\
\text { value }\end{array}$} \\
\hline & & & & & 5 & 10 & 25 & 50 & 75 & 90 & 95 & \\
\hline ortho- $\mathrm{PO}_{4}$, dissolved & -- & -- & -- & -- & $\overline{--}$ & $\because-$ & -- & $\overline{--}$ & -- & -- & -- & -- \\
\hline ortho- $\mathrm{PO}_{4}$, total & 2 & 21 & 0.01 & 0.01 & 0.01 & 0.01 & 0.01 & 0.01 & 0.09 & 0.45 & 0.48 & 0.48 \\
\hline
\end{tabular}




\section{REFERENCES}

Dugan, J.T., and Schild, D.E., 1992, Water-level changes in the High Plains aquifer-Predevelopment to 1990: U.S. Geological Survey WaterResources Investigations Report 91-4165, 55 p.

Havens, J.S., 1977, Reconnaissance of the water resources of the Lawton quadrangle, southwestern Oklahoma: Oklahoma Geological Survey Hydrologic Atlas 6, 4 sheets, scale 1:250,000.

Havens, J.S., 1992, Oklahoma, in Dugan, J.T., and Schild, D.E., 1992, Water-level changes in the High Plains aquifer-Predevelopment to 1990: U.S. Geological Survey Water-Resources Investigations Report 91-4165, 55 p.

Hem, J.D., 1985, Study and interpretation of the chemical characteristics of natural water: U.S. Geological Survey Water-Supply Paper 2254, 263 p.

Johnson, K.S., 1990, Hydrogeology and Karst of the Blaine Gypsum-Dolomite Aquifer, Southwestern Oklahoma: Geological Society of America, 1990, Special Publication 90-5, Field Trip Number 15 Guidebook, Annual Meeting, Dallas, Texas.

Johnson, K.S., Runkle, D.L., and Becker, M.F., 1990, Hydrogeology of the Rush Springs-Marlow Aquifer in the Anadarko Basin, West-Central Oklahoma, U.S.A.: in Proceedings of the International Conference on Groundwater in Large Sedimentary Basins, Perth, Australia, 1990, p. 100-109.

Kreitler, C.W., and Jones, D.C., 1975, Natural soil nitrate: The cause of the nitrate contamination of ground water in Runnels County, Texas: Ground Water, v. 13 , no. 1 , p. 53-61.

National Academy of Science, 1977, Drinking water and health: Washington, D.C., National Academy of Sciences, $939 \mathrm{p}$.
Oklahoma State Department of Health, 1992, Public water supply regulations, Section 310 , Chapter 3301-3.

Pettyjohn, W.A., Savoca, M.E., and Self, Dale, 1991, Regional assessment of aquifer vulnerability and sensitivity in the conterminous United States: Ada, Oklahoma., Robert S. Kerr Environmental Research Laboratory, EPA/600/2-91/043, 319p.

Runkle, D.L., and Johnson, K.S., 1988, Hydrogeologic study of a gypsum-dolomite karst aquifer in southwestern Oklahoma and adjacent parts of Texas, U.S.A.: Proceedings of the International Association of Hydrogeologists 21st Congress, Karst hydrogeology and karst environmental protection, October 10-15, 1988, Guilin City, Peoples Republic of China, v. 21, part 1, p. 400-405.

Seaber, P.R., Kapinos, F.P., and Knapp, G. L., 1987, Hydrologic unit maps: U.S. Geological Survey Water-Supply Paper 2294, 63 p.

Solley, W.B., Pierce, R.R., and Perlman, H.A., 1993, Estimated use of water in the United States in 1990: U.S. Geological Survey Circular 1081, 76 p.

U.S. Environmental Protection Agency, 1986, Quality criteria for water: U.S. Environmental Protection Agency 440/5-86-001.

-.--1992, Maximum contaminant levels (Subpart B of part 141, National interim primary drinking-water regulation): U.S. Code of Federal Regulations, Title 40, Part 141.62, revised as of January 30, 1991.

Weeks, J.B., and Gutentag, E.D., 1981, Bedrock geology, altitude of base, and 1980 saturated thickness of the High Plains aquifer in parts of Colorado, Kansas, Nebraska, New Mexico, Oklahoma, South Dakota, Texas, and Wyoming: U.S. Geological Survey Hydrologic Investigations Atlas $\mathrm{HA}-648$, scale $1: 250,000,2$ sheets. 